\title{
El cambio climático y los impactos socioeconómicos sobre la zona costera e insular colombiana
}

\section{Climate change and socioeconomic impacts on the Colombian coastal and insular area}

\author{
Desireé Hernández Narváez, Alejandra Vega Cabrera, Anny Zamora Bornachera y \\ $\begin{array}{lll}\text { (iD) } 0000-0001-6555-1290 & \text { (ID) } 0000-0003-1472-9209 & \text { (ID) } 0000-0003-4118-4195\end{array}$
}

Paula Cristina Sierra-Correa

0000-0001-7252-7993

Instituto de Investigaciones Marinas y Costeras “José Benito Vives De Andréis” INVEMAR, Santa Marta D.T.C.H., Colombia.desiree.hernandez@ invemar.org.co; alejandra.vega@invemar.org.co; anny.zamora@invemar.org.co; paula.sierra@invemar.org.co

\section{RESUMEN}

$\mathrm{E}$ 1 cambio climático tiene incidencias a nivel global, con efectos sobre los sistemas naturales y humanos, y en particular las zonas costeras han sido reconocidas como áreas sensibles a las amenazas de ascenso en el nivel del mar (ANM) y erosión costera. Este ejercicio se realizó con el fin de identificar los impactos del cambio climático a nivel socioeconómico en la zona costera de Colombia, compuesta por 12 departamentos que abarcan 60 municipios enmarcados en diez Unidades Ambientales Costeras (UAC). Metodológicamente, se definieron 23 indicadores utilizando el enfoque de riesgo, que conjuga la exposición (14 indicadores), sensibilidad (6 indicadores) y capacidad adaptativa (3 indicadores), enmarcados en las dimensiones de seguridad alimentaria, hábitat humano e infraestructura. Para esto, se construyeron bases de datos con información oficial sobre los elementos socioeconómicos expuestos y se empleó el registro de las áreas afectadas por ANM y erosión costera elaborados por Invemar en el marco de la Tercera Comunicación Nacional de Cambio Climático. Con estos datos se construyeron las matrices de indicadores y se calcularon los niveles de afectación en cada indicador utilizando la distribución por quintiles. Los resultados muestran que hacia el año 2100 cerca de 5\% de la población y 4,3\% de las viviendas se afectarían por ANM, especialmente en los municipios de Guapi, Mosquera (Cauca) y La Tola (Nariño) en la región pacífica y Remolino, Sitio Nuevo y Pueblo Viejo (Magdalena) en el Caribe; además, las áreas turísticas podrían perder $13 \%$ a causa de la erosión costera y $5,9 \%$ de la infraestructura portuaria y $12 \%$ de las vías podrían inundarse por ANM. Estos resultados son un insumo para apoyar la planificación territorial, así como para la formulación de los planes municipales y sectoriales de gestión del cambio climático a nivel costero en Colombia.

PALABRAS CLAVE: Indicadores, Vulnerabilidad, Amenaza, Marino Costera, Cambio Climático.

\section{ABSTRACT}

$\mathrm{C}$

limate change has a global-level impact, with effects on natural and human systems, and in particular coastal zones have been recognized as area sensitive to threats of sea level rise (SLR) and coastal erosion. This exercise was carried out in order to identify the impacts of climate change at a socioeconomic level in Colombia's coastal zone, which is composed of 12 departments with 60 municipalities framed within ten Coastal Environmental Units (UAC). Methodologically, 23 indicators were defined using the risk approach, that combines the exposure (14 indicators), sensitivity (6 indicators) and adaptive capacity (3 indicators), framed within food security, human habitat, and infrastructure dimensions. To do this, official information databases were built regarding the socioeconomic elements exposed, combined with the use of the SLR and coastal erosion-affected areas report, elaborated by Invemar within the Third National Communication on Climate Change framework. With this report data, indicator matrices were built and the levels of affectation in each indicator were calculated using distribution by quintiles. The results show that towards the year 2100 , about $5 \%$ of the population and $4.3 \%$ of houses will be affected by SLR, especially in the Guapi and Mosquera (Cauca) and La Tola (Nariño) municipalities in the Pacific region and Remolino, Sitio Nuevo and Pueblo Viejo (Magdalena) municipalities in the Caribbean. In addition, tourist areas could lose $13 \%$ due to coastal erosion, and $5.9 \%$ of the port infrastructure and $12 \%$ of the roads could be flooded by SLR. These results constitute an input to support territorial planning, as well as the formulation of municipal and sectoral plans for climate change management on Colombia's coasts.

KEYWORDS: Indicators, Vulnerability, Threat, Coastal Marine, Climate Change.

DOI: 10.25268/bimc.invemar.2019.48.2.764. 


\section{INTRODUCCIÓN}

Las incidencias del cambio climático se han evidenciado a nivel global, con impactos negativos reflejados tanto en los sistemas naturales como en los humanos, en todos los continentes y océanos del planeta, y particularmente las zonas costeras han sido reconocidas como áreas sensibles a este fenómeno (IPCC, 2014; Vides y Sierra-Correa, 2014; Petzold y Beate, 2015; Tragaki et al, 2018; Armanfar et al, 2019). En este sentido, el Panel Intergubernamental de Cambio Climático (IPCC por sus siglas en inglés) elaboró cinco informes de evaluación sobre impactos, vulnerabilidad y adaptación al cambio climático observados a nivel mundial, dando pautas para la continuidad de estudios más detallados (IPCC, 1990, 1995, 2001, 2007, 2014)

La Convención Marco de las Naciones Unidas sobre Cambio Climático (CMNUCC) define este fenómeno como el "cambio de clima atribuido directa o indirectamente a la actividad humana que altera la composición de la atmósfera global y que se suma a la variabilidad natural del clima observada durante períodos de tiempo comparables", cuya persistencia es generalmente de decenios o más (IPCC, 2014; Camare y Lane, 2015). Así mismo, el IPCC define la vulnerabilidad como la predisposición o propensión a ser afectado negativamente, concepto que se encuentra en función de la exposición, sensibilidad y capacidad adaptativa. La exposición es la presencia de elementos (personas, medios de subsistencia, ecosistemas, recursos ambientales, infraestructura, activos económicos, sociales o culturales) en lugares o entornos que podrían verse afectados negativamente: la sensibilidad es el grado en que un sistema o especie resultan afectados por el cambio climático, este término se encuentra directamente relacionado con las condiciones socioeconómicas, naturales y políticas de una población, por tanto, depende de la gestión y el acceso a recursos que tenga; y la capacidad adaptativa se refiere a la posibilidad que tienen los sistemas, las instituciones, las personas y otros organismos para adaptarse a los daños, aprovechar las oportunidades, afrontar consecuencias y moderar o evitar los pérdidas (Klein et al, 2001; Gallopín, 2006; Olivo-Garrido et al, 2012; Lampis, 2013; IPCC, 2014).

Por su parte, los impactos del cambio climático se definen como los efectos, consecuencias y resultados sobre los sistemas naturales y humanos, causados por este fenómeno y a la vulnerabilidad de las sociedades o los sistemas expuestos. Son producto de las amenazas,

\section{INTRODUCTION}

The effects of climate change have been evident at global level, with negative impacts reflected in both natural and human systems all over the planet, with coastal areas being recognized as particularly sensitive to this phenomenon (IPCC, 2014; Vides and Sierra-Correa, 2014; Petzold and Beate, 2015; Tragaki et al., 2018; Armanfar et al., 2019). In this respect, the Intergovernmental Panel on Climate Change (IPCC) prepared five assessment reports on impacts, vulnerability and adaptation to climate change observed worldwide, providing guidelines for the continuity of more detailed studies (IPCC, 1990, 1995, 2001, 2007, 2014).

The United Nations Framework Convention on Climate Change (UNFCCC), defines this phenomenon as follows, "a change of climate which is attributed directly or indirectly to human activity that alters the composition of the global atmosphere and which is in addition to natural climate variability observed over comparable time periods", whose persistence generally lasts for decades or more (IPCC, 2014; Camare and Lane, 2015). Likewise, the IPCC defines vulnerability as the propensity or predisposition to be adversely affected, a concept based on exposure, sensitivity and the capacity to cope and adapt. Exposure is the presence of elements (people, means of subsistence, ecosystems, environmental resources, infrastructure, economic, social or cultural assets) in places or environments that could be negatively affected. Sensitivity is the degree to which a system or species is affected by climate change; this term is directly related to the socioeconomic, natural and political conditions of a population, and therefore depends on its access to resources and their management. Finally, adaptive capacity refers to the ability of systems, institutions, individuals and other agencies to adapt to damage, seize opportunities, cope with consequences and moderate or avoid losses (Klein et al., 2001; Gallopín, 2006; OlivoGarrido et al., 2012; Lampis, 2013; IPCC, 2014).

The impacts of climate change are defined as the effects, consequences and results on natural and human systems caused by this phenomenon and to the vulnerability of exposed societies or systems. They are the product of threats, corresponding to changes in atmospheric temperature, changes in precipitation, sea level rise (SLR), coastal erosion, marine acidification and changes in sea surface temperature (SST). Coastal systems are particularly sensitive to SLR, SST, marine acidification and coastal 
correspondientes a cambios en la temperatura atmosférica, cambios en las precipitaciones, ascenso en el nivel del mar (ANM), erosión costera, acidificación marina y cambios en la temperatura superficial del mar (TSM). Los sistemas costeros son particularmente sensibles al ANM, TSM, acidificación marina y erosión costera (Diez, 2000; IPCC, 2014; Slangen et al., 2014).

Los impactos tienen repercusiones a nivel socioeconómico, en los asentamientos humanos, en las actividades económicas y en las condiciones de vida. En este sentido, la vulnerabilidad es determinada por la desigualdad en el acceso a los recursos y no únicamente por los impactos de los eventos naturales (Yáñez-Arancibia, 2014; Mussetta et al., 2017).

Es así como se prevé que un ANM ocasionaría impactos negativos como inmersión, inundación y erosión costera. A su vez, la exposición podría aumentar en los decenios futuros, debido al incremento de la población y de los activos económicos (bienes y servicios) (Diez, 2000; IPCC, 2014); se estima que países ubicados a baja latitud, específicamente en América Central y del Sur, afrontarían fuertes impactos y daños debido a inundaciones causadas por el ANM, que se reflejarían en altos costos de reparación y adaptación (Day et al., 2011; Wong et al., 2014); tal es el caso de países como Venezuela, Uruguay y Perú, que de acuerdo con estudios realizados (Giménez y Lanfranco, 2012; Tejeda, 2018; Nagy et al., 2019), podrían afrontar consecuencias socioeconómicas relacionadas con afectaciones en los hábitats humanos costeros, en actividades productivas (por ejemplo el turismo) e infraestructura. En Venezuela se identificaron riesgos por ANM y erosión costera para dos áreas (sector Cabo Codera-Parque Nacional Laguna de Tacarigua y Barcelona-Puerto La Cruz-Guanta), las cuales tienen niveles altos de vulnerabilidad, exacerbados por las intervenciones antrópicas (Olivo et al., 2001).

Así mismo, existen casos como el Peloponeso (sur de Grecia), donde se identificaron siete comunidades municipales a lo largo de la costa noroeste con alto riesgo y muy alta vulnerabilidad a las amenazas del cambio climático (Tragaki et al., 2018). En Malasia se esperan repercusiones negativas en actividades económicas como la agricultura y silvicultura, impactos sobre la biodiversidad, los recursos costeros y marinos, la salud pública y la energía (Kuok Ho, 2019). En México, por su parte, el área más vulnerable de las costas de los estados de Tabasco y Campeche incluyen 437.836 habitantes de ciudades portuarias que podrían verse afectados debido a inundaciones por ANM (Ramos- erosion (Diez, 2000; IPCC, 2014; Slangen et al., 2014).

The impacts have repercussions at the socioeconomic level, on human settlements, on economic activities and on living conditions. In this sense, vulnerability is determined by inequality in access to resources and not only by the impacts of natural events (Yáñez-Arancibia, 2014; Mussetta et al., 2017).

Thus, SLR is expected to cause negative impacts such as immersion, flooding, and coastal erosion. In turn, exposure could increase in future decades due to increased population and economic assets (goods and services) (Diez, 2000; IPCC, 2014). It is estimated that countries located at low latitudes, specifically in Central and South America, will face strong impacts and damage due to floods caused by SLR, reflected in high restoration and adaptation costs (Day et al., 2000; IPCC, 20114, 2014; Wong et al., 2014). Such is the case for countries such as Venezuela, Uruguay, and Peru, which according to a number of studies (Giménez and Lanfranco, 2012; Tejeda, 2018; Nagy et al., 2019) could suffer the socioeconomic consequences of the effects on coastal human habitats, productive activities (e.g., tourism), and infrastructure. In Venezuela, SLR and coastal erosion risks were identified for two areas (Cabo Codera-Parque Nacional Laguna de Tacarigua and Barcelona-Puerto La Cruz-Guanta), both with high levels of vulnerability, exacerbated by anthropogenic interventions (Olivo et al., 2001).

There are also cases such as the Peloponnese (southern Greece), where seven municipal communities along the northwest coast were identified as high risk and very high vulnerability to the threats of climate change (Tragaki et al., 2018). In Malaysia, negative impacts are expected on economic activities such as agriculture and forestry, biodiversity, coastal and marine resources, public health and energy (Kuok Ho, 2019). In Mexico, the most vulnerable area on the coasts of the states of Tabasco and Campeche includes 437,836 inhabitants of port cities that could be affected by flooding due to SLR (Ramos-Reyes et al., 2016). In Argentina, 25\% of the lowlands in the province of Río Negro are highly vulnerable due to SLR and marine erosion (Kokot et al., 2004). Meanwhile, in Brazil the beaches of the state of Bahia will be reduced by the effects of coastal erosion, and tourist facilities and spaces will be affected by flooding caused by the SLR (Da Cruz, 2009).

In the national context, there have been three National Communications to the United Nations Framework Convention on Climate Change (UNFCCC) (IDEAM- 
Reyes et al., 2016). En Argentina, se evidencia muy alta vulnerabilidad en $25 \%$ de las áreas bajas de la provincia de Río Negro debido al ANM y erosión marina (Kokot et al., 2004). Mientras que en Brasil las playas del estado de Bahía tendrán reducciones por efectos de la erosión costera y el equipamiento y los espacios turísticos se afectarán por inundaciones producto del ANM (Da Cruz, 2009).

En el contexto nacional, se encuentran las tres comunicaciones nacionales ante la Convención Marco de las Naciones Unidas sobre Cambio Climático (CMNUCC) (IDEAM-PNUD, 2001, 2010; IDEAM et al, 2017). En este sentido, en la Primera Comunicación Nacional (2001) se analizó el período 1990-1994, los resultados indicaron que un ANM de un metro, hacia finales del siglo XXI, causaría afectaciones sobre 1,4 millones de habitantes del país (4\%). Por su parte, la vulnerabilidad de las viviendas para la región Caribe es de $9 \%$ en las zonas urbanas y de $46 \%$ en la zona rural; en el Pacífico esta proporción alcanza 45\% (IDEAM - PNUD, 2001).

Por otro lado, en la región Caribe los resultados prevén inundaciones por ANM en las áreas agropecuarias, con una proporción de 4,9\%; específicamente el banano se vería afectado en $39,2 \%$ y la palma africana en $9,7 \%$, con repercusiones económicas para la ciudad de Santa Marta y el departamento del Magdalena. En el sector industrial se afectaría 75,3\% de las áreas ocupadas por establecimientos manufactureros en Barranquilla y $99,7 \%$ en Cartagena. $\mathrm{Y}$, finalmente, $44,8 \%$ de la infraestructura vial terrestre presenta alta vulnerabilidad (IDEAM - PNUD, 2001).

En 2010, el Banco Interamericano de Desarrollo (BID) realizó un estudio de vulnerabilidad y adaptación al cambio climático en Mesoamérica. Los resultados para Colombia indicaron una alta sensibilidad en las zonas costeras. En estas existen varios elementos expuestos, como la agricultura y los centros poblados; a su vez, los altos niveles de pobreza se suman como un factor determinante de sensibilidad a los efectos del cambio climático (BID, 2010).

Así mismo, en 2010 se elaboró la Segunda Comunicación Nacional de Cambio Climático, donde se analizaron los años 2000 y 2004.Los resultados indicaron que en la región Caribe $51 \%$ de las áreas urbanas sufrirían inundaciones por ANM y en el Pacífico esta cifra ascendería a $63 \%$ con pérdidas en infraestructura principalmente. En términos de población costera se proyectan 9'000.000 de habitantes para 2030 , de los cuales $4 \%$ se afectaría por la misma amenaza (Caribe: 80\%, Pacífico: 20\%). Para los sectores agrícola, ganadero, industrial, forestal y minero, el
UNDP, 2001, 2010; IDEAM et al., 2017). The First National Communication (2001) analyses the 1990-1994 period. The results indicate that SLR of one meter, towards the end of the 21st century, would affect 1.4 million of the country's inhabitants (4\%). The vulnerability of housing in the Caribbean region is $9 \%$ in urban areas and $46 \%$ in rural areas. In the Pacific, this proportion reaches $45 \%$ (IDEAM - PNUD, 2001).

In the Caribbean region, the results foresee flooding by SLR in agricultural areas, with a proportion of $4.9 \%$; specifically, banana will be affected by $39.2 \%$ and African palm by $9.7 \%$, with economic repercussions for the city of Santa Marta and the department of Magdalena. In the industrial sector, $75.3 \%$ of the areas occupied by manufacturing establishments in Barranquilla and $99.7 \%$ in Cartagena will be affected. And finally, $44.8 \%$ of terrestrial road infrastructure is highly vulnerable (IDEAM - PNUD, 2001).

In 2010, the Inter-American Development Bank (IDB) conducted a study of vulnerability and adaptation to climate change in Mesoamerica with results indicating high sensitivity in Colombia's coastal areas. Besides the various elements exposed in these areas, such as agriculture and population centers, high levels of poverty are added as a determining factor of sensitivity to the effects of climate change (BID, 2010).

Similarly, the Second National Communication on Climate Change was prepared in 2010, analyzing the years 2000 and 2004. The results indicate that, in the Caribbean region, $51 \%$ of urban areas will suffer flooding by SLR and in the Pacific, this figure rises to $63 \%$ with losses mainly in terms of infrastructure. In terms of coastal population, $9,000,000$ inhabitants are projected for the year 2030, of which $4 \%$ will be affected by the same threat (Caribbean: 80\%, Pacific: 20\%). For the agricultural, livestock, industrial, forestry and mining sectors, the GDP affected will be between $0.4 \%$ and $3 \%$ by 2100 , and damage due to the loss of hotel infrastructure will reach 12 million dollars (IDEAM - PNUD, 2010).

The studies on vulnerability to climate change for Colombia carried out at national and even departmental levels served as reference to develop a vulnerability analysis within the framework of the Third National Communication on Climate Change (TCNCC), conducted at municipal level for the country's coastal zone. In it information regarding the socioeconomic component for this area was updated, this being the subject of interest for this document. Thus, socioeconomic variables were crossed with SLR and coastal erosion threat 
PIB afectado estaría entre $0,4 \%$ y $3 \%$ para 2100 y los daños por pérdidas de infraestructura hotelera llegarían a 12 millones de dólares (IDEAM - PNUD, 2010).

Los estudios sobre vulnerabilidad al cambio climático para Colombia elaborados a escala nacional e incluso departamental sirvieron como punto de referencia para el desarrollo de un análisis de vulnerabilidad enmarcado en la Tercera Comunicación Nacional de Cambio Climático (TCNCC), realizado a nivel municipal para la zona costera del país; donde se actualizó el conocimiento específico para el componente socioeconómico de esta área, el cual constituye el tema de interés para este documento. Es así como las variables socioeconómicas se cruzaron con los modelos de las amenazas de ANM y erosión costera a una escala local. El modelo de ANM se elaboró a partir de escenarios de máximas emisiones de Gases Efecto Invernadero (GEI), donde en 2040 el nivel del mar tendría un aumento de $18 \mathrm{~cm}$, a 2070 sería de $29 \mathrm{~cm}$ y a $2100 \mathrm{de} 40 \mathrm{~cm}$.

A partir de este nuevo estudio a escala local, surge la pregunta ¿Cuáles son los impactos socioeconómicos a nivel municipal, causados por las amenazas del cambio climático sobre la zona costera e insular de Colombia? Este trabajo se propone mostrar los resultados obtenidos a escala municipal a nivel socioeconómico. Dichos resultados permiten tener un acercamiento a los posibles impactos sociales y económicos ocasionados por las amenazas del ANM y erosión para las zonas costeras del Caribe, Pacífico e Insular del país.

\section{ÁREA DE ESTUDIO}

Colombia se encuentra ubicada en el extremo noroccidental de Suramérica y posee una extensión total aproximada de $2.070 .408 \mathrm{~km}^{2}$ de los cuales 1.178 .396 $\mathrm{km}^{2}$ corresponden a tierras emergidas, continentales e insulares (MMA, 2001). Su zona costera continental e insular tiene un área aproximada de $16.128 \mathrm{~km}^{2}$ que abarcan longitudinalmente $3532 \mathrm{~km}$ de costa sobre el océano Pacífico y el mar Caribe y $892.102 \mathrm{~km}^{2}$ de aguas jurisdiccionales. Territorialmente está compuesta por 10 Unidades Ambientales Costeras (UAC), que integran 12 departamentos y 60 municipios costeros (INVEMARIDEAM, 2017) (mapa con las UAC, los departamentos y los 60 municipios costeros) (Figura 1). models at local scale. The SLR model was developed from scenarios of maximum Greenhouse Gas (GHG) emissions, indicating that by 2040, the sea level will rise by $18 \mathrm{~cm}$; by 2070 , it will rise by $29 \mathrm{~cm}$; and by 2100 by $40 \mathrm{~cm}$.

From this new local scale study, the following question arises: What is the municipal level socioeconomic impacts caused by the threats of climate change on the coastal and insular parts of Colombia? This paper aims to show the results obtained at socioeconomic municipal scale. These results enable an approach to the possible social and economic impacts caused by the threats of SLR and erosion for the coastal areas of the Caribbean, the Pacific, and Insular parts of the country.

\section{STUDY AREA}

Colombia, located in the extreme northwest of South Am erica, has a total area of approximately 2,070,408 $\mathrm{km}^{2}$ of which $1,178,396 \mathrm{~km} 2$ correspond to emerged, continental, and insular lands (MMA, 2001). Its continental and insular coastal zone has an approximate area of 16,128 $\mathrm{km}^{2}$ that longitudinally includes $3,532 \mathrm{~km}$ of coast on the Pacific Ocean and the Caribbean Sea and 892,102 km2 of jurisdictional waters. The territory is composed of 10 Coastal Environmental Units (UAC), which integrate 12 departments, and 60 coastal municipalities (INVEMARIDEAM, 2017) (map with UAC, departments, and 60 coastal municipalities) (Figure 1).

\section{METHODOLOGY}

For this study, a methodological approach was taken to the proposals of the IPCC. The focus is on risk based on the integration of three main elements: vulnerability, exposure, and hazards (IPCC, 2014). This methodology was adapted for the TCNCC and developed in a joint project with IDEAM; the marine-coastal component being a contribution to the vulnerability analysis at municipal level throughout the Colombian territory.

This work integrates the analysis of socioeconomic data from 60 coastal municipalities in Colombia (scale 1:100,000), which were contrasted with the threats of SLR and coastal erosion, in order to estimate the impacts for the years 2040, 2070, and 2100. Official sources of information were selected given that they are kept updated, permanently available, and can be used to replicate the exercise in the future. The analysis was grouped into three dimensions: 


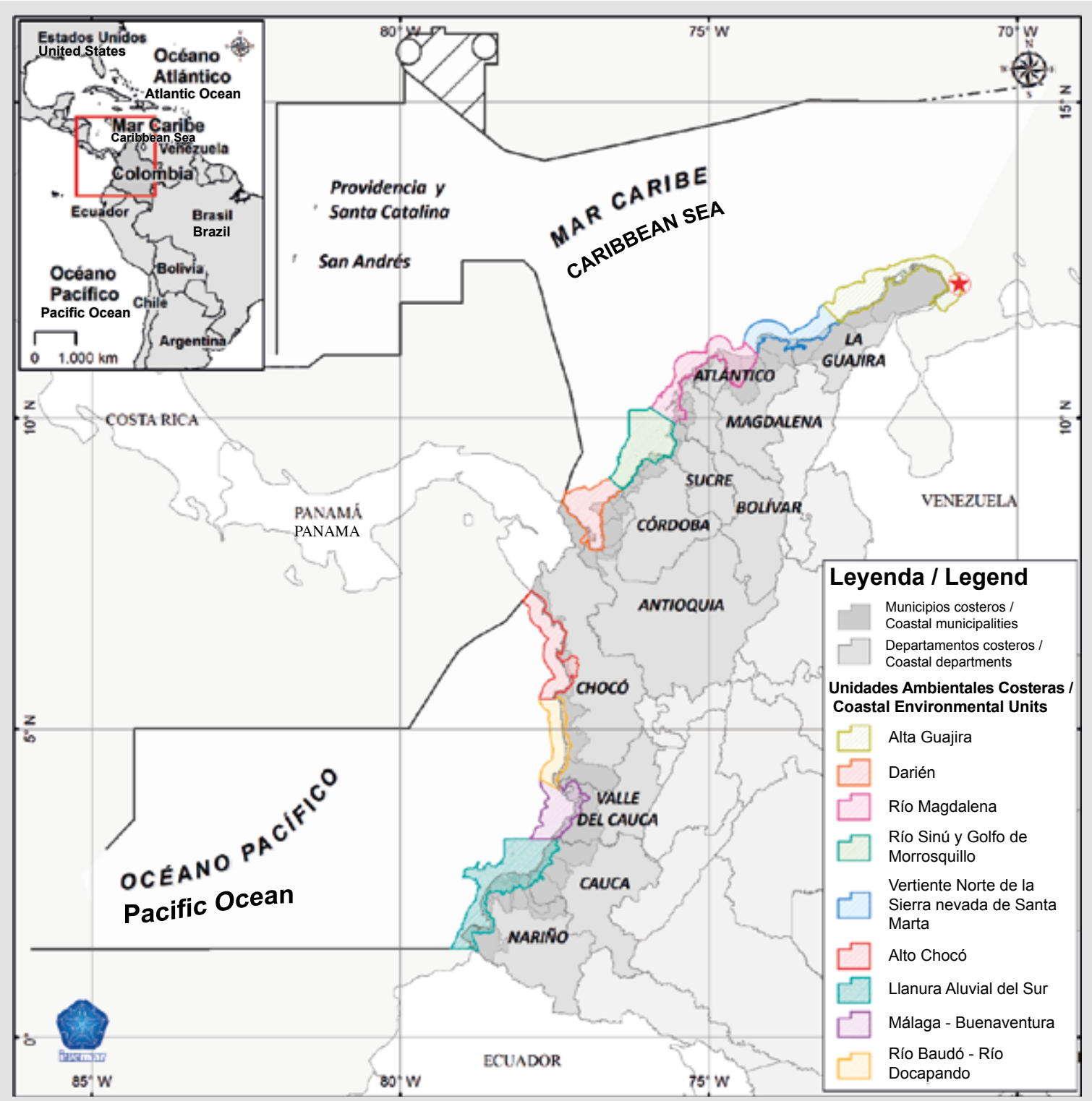

Figura 1. Delimitación de la zona de estudio. Fuente: LabsisINVEMAR (2018).

Figure 1. Delimitation of the study area. Source: Labsis-INVEMAR (2018).

\section{METODOLOGÍA}

Para la elaboración de este estudio se hizo una aproximación metodológica a los planteamientos del IPCC, el enfoque es el riesgo a partir de la integración de tres elementos principales: la vulnerabilidad, la exposición y los peligros (IPCC, 2014). Esta metodología se adaptó para la TCNCC y se desarrolló en un trabajo realizado en conjunto con el IDEAM; siendo el componente marino-costero un aporte para el análisis de vulnerabilidad a escala municipal en todo el territorio colombiano. food security, human habitat, and infrastructure. For each dimension, threat, sensitivity, and adaptive capacity matrices were applied.

According to the methodological scheme, the first step is the identification of relevant socioeconomic elements, for which a bibliographic review was performed to determine which demographic, economic and infrastructure characteristics and features relating to living conditions were most representative in the study municipalities. The second step involved the search for and compilation of official information from secondary sources in a time series 
Este trabajo integra el análisis de datos socioeconómicos de 60 municipios costeros de Colombia (escala 1:100.000), los cuales fueron contrastados con las amenazas de ANM y erosión costera, con el fin de estimar los impactos para los años 2040, 2070 y 2100. Se seleccionaron fuentes oficiales de información, debido a que se mantendrán en constante actualización y disponibilidad y pueden ser utilizadas para replicar el ejercicio a futuro. El análisis se agrupó en tres dimensiones: seguridad alimentaria, hábitat humano e infraestructura; para cada dimensión se construyeron matrices de amenaza, sensibilidad y capacidad adaptativa; en la figura 2, se muestran los pasos para el desarrollo metodológico. between 2011-2015. Here we identified the country's official institutions such as the National Administrative Department of Statistics (DANE), the Ministry of Transportation, the Ministry of Health and Social Protection, the National Planning Department (DNP), the Marine and Coastal Research Institute (INVEMAR); the different departmental and municipal development plans; and the type of information they generate, from which the data used were obtained. The time frame was defined in order to observe the changes between the Second National Communication on Climate Change (2010) and up until 2015, when the updating of the vulnerability analysis in the TCNCC began.

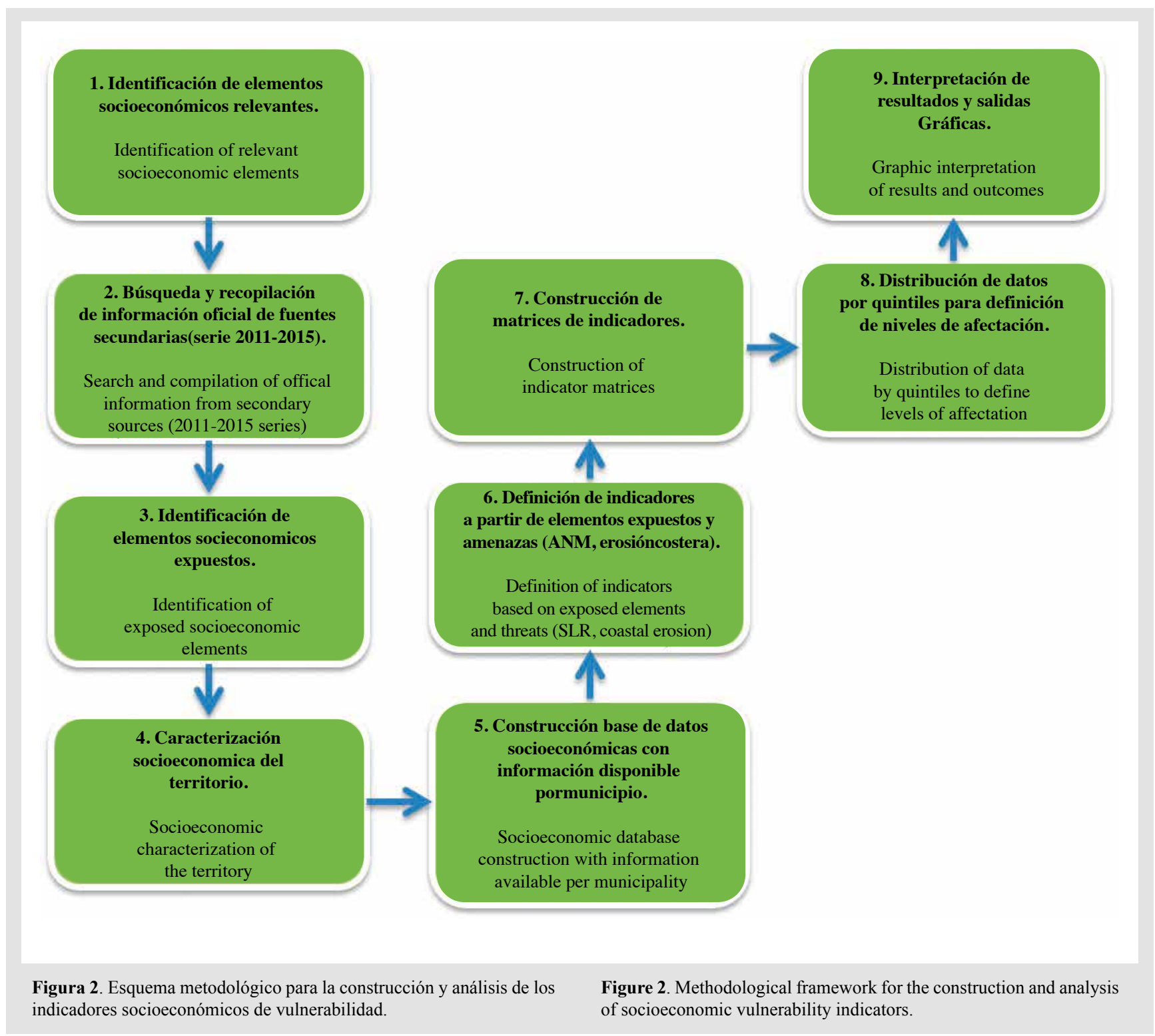


De acuerdo con el esquema metodológico, el primer paso es la identificación de elementos socioeconómicos relevantes, donde se realizó una revisión bibliográfica para determinar cuáles características demográficas, de condiciones de vida, económicas y de infraestructura fueron más representativas en los municipios de estudio. El segundo paso es la búsqueda y recopilación de información oficial de fuentes secundarias en una serie de tiempo entre 20112015, y en este se identificaron las instituciones oficiales del país como el Departamento Administrativo Nacional de Estadística -DANE-, Ministerio de Transporte, Ministerio de Salud y Protección Social, Departamento Nacional de Planeación - DNP,- Instituto de Investigaciones Marinas y Costeras - Invemar-, los diferentes planes de desarrollo departamentales y municipales, y el tipo de información que generan, de las cuales se descargaron los datos utilizados; la temporalidad se definió con el fin de observar los cambios entre la segunda comunicación nacional de cambio climático (2010) hasta 2015 cuando se inició el proceso de actualización del análisis de vulnerabilidad en la TCNCC.

Para el tercer paso, se identificaron los elementos socioeconómicos expuestos a partir de una revisión de antecedentes nacionales e internacionales relacionados con estudios sobre cambio climático y de literatura científica sobre la manera como se impacta cada elemento de las zonas costeras. Lo anterior llevó a la caracterización socioeconómica (cuarto paso), como integración de toda la información obtenida y tener una visión completa del territorio. En el quinto paso, se organizaron las bases de datos por variables (número de habitantes, número de viviendas, tamaño de áreas municipales, de usos agropecuarios, usos turísticos, de infraestructura costera, entre otros) para cada municipio, utilizando el programa Excel.

A continuación, se definieron los indicadores (sexto paso), para esto, las bases de datos fueron depuradas dejando únicamente las variables correspondientes a los elementos expuestos. En este punto, se utilizó la información de los modelos de inundación por ANM y erosión costera elaborados por Invemar (2017) para la zona marino-costera de Colombia, donde se reportaron las áreas afectadas por estas amenazas a nivel municipal, proyectadas a los años 2040, 2070 y 2100 (INVEMAR-IDEAM, 2017). En el séptimo paso, se agruparon estos indicadores en tablas de Excel (matrices) por las tres dimensiones (seguridad alimentaria, hábitat humano e infraestructura); cada variable socioeconómica se cruzó con las áreas afectadas para obtener
For the third step, the socioeconomic elements exposed were identified from a review of national and international antecedents related to climate change studies and scientific literature on how each component of the coastal zone is impacted. This led to a socioeconomic characterization (fourth step), in order to integrate all the information obtained and to have a complete vision of the territory. In the fifth step, databases were organized by variables (number of inhabitants, number of dwellings, size of municipal areas, agricultural uses, tourist uses, coastal infrastructure, among others) for each municipality, using the Excel program.

The indicators were then defined (step six) by leaving only the variables corresponding to the exposed elements in the databases. At this point, the information from the SLR flood and coastal erosion models elaborated by Invemar (2017) was used for Colombia's marinecoastal zone, where the areas affected by these threats were reported at municipal level, projected to 2040, 2070, and 2100 (INVEMAR-IDEAM, 2017). In the seventh step, these indicators were grouped in Excel tables (matrices) by the three dimensions (food security, human habitat, and infrastructure). Each socioeconomic variable was crossed with the affected areas to obtain the threat indicators. The sensitivity is observed in the intrinsic characteristics of the populations, for which the data for the percentage of Unsatisfied Basic Needs (UBN), Gross Domestic Product (GDP) and housing deficiency were used. Finally, the adaptive capacity was calculated using data relating to economic investment made in environmental issues where climate change is included by municipality (Table 1 ).

The following formulas were used to calculate the percentage of areas affected (municipal, agricultural, tourist, and port areas):

$$
\% A S L R=\frac{A S L R}{A T m} ; \quad \% A E=\frac{A E}{A T m}
$$

Where \%ASLR and \%AE, are the percentages of areas affected by SLR and coastal erosion; ASLR and AE correspond to the areas potentially floodable and lost by both threats, and ATm is the total size of each area.

The following formulas were used to calculate the population, dwellings and roads affected in each of the cases: 
los indicadores de amenaza; la sensibilidad se observa en las características intrínsecas de las poblaciones, por lo tanto se utilizaron los datos de porcentaje de Necesidades Básicas Insatisfechas (NBI), el Producto Interno Bruto (PIB) y deficiencia en las viviendas; y la capacidad adaptativa fue calculada con datos de inversión económica realizada en temas ambientales donde se incluye el cambio climático por municipio (Tabla 1).

Para el cálculo del porcentaje de afectación de las áreas (áreas municipales, agropecuarias, turísticas y de zona portuaria) se utilizaron las fórmulas:

$$
\% \mathrm{AANM}=\frac{\mathrm{AANM}}{A T m} ; \quad \% \mathrm{AE}=\frac{\mathrm{AE}}{A T m}
$$

Donde \%AANM y \%AE, son los porcentajes de áreas afectadas por ANM y erosión costera; AANM y AE corresponden a las áreas potencialmente inundables y perdidas por ambas amenazas y ATm es el tamaño total de cada área.

Para calcular la población, viviendas y vías afectadas se emplearon las siguientes fórmulas en cada uno de los casos:

$$
\% X \text { ANM }=\frac{X \text { ANM }}{X T m} ; \quad \% X \text { ANM }=\frac{X \text { ANM }}{X T m}
$$

Donde $\% X \mathrm{ANM}$ y $\% X \mathrm{AE}$, son los porcentajes de afectación de las tres variables debido al ANM y la erosión costera; $X \mathrm{ANM}$ y $X \mathrm{E}$ corresponden al número de habitantes, viviendas y vías ubicadas en las zonas susceptibles de inundación y pérdida por ambas amenazas y $X T \mathrm{~m}$ es el tamaño total de cada variable por municipio.

Una vez obtenidos los datos de afectaciones, se procede a realizar la distribución de los resultados por quintiles en cada matriz, lo cual permitió obtener cinco rangos equivalentes a los niveles de afectación para cada indicador (muy bajo, bajo, medio, alto y muy alto). Los quintiles se obtienen organizando los datos de menor a mayor y dividiéndolos en cinco partes iguales (Vargas, 1995; Benjumea et al., 2006); en Excel se utilizó la fórmula "PERCENTIL.INC" para realizar el cálculo.

Las afectaciones fueron estimadas para los años 2040, 2070 y 2100, de acuerdo con la disponibilidad de datos, y se exponen los mayores impactos, proyectados para final de siglo. En este sentido, se trabajó con el supuesto de

$$
\% X S L R=\frac{X S L R}{X T m} ; \quad \% X S L R=\frac{X S L R}{X T m}
$$

Where \%XSLR and \%XAE, are the percentages of affectation of the three variables due to SLR and coastal erosion; XSLR and XE correspond to the number of inhabitants, dwellings and roads located in areas susceptible to flooding and loss by both hazards, and XTm is the total size of each variable per municipality.

Once the data on affectations were obtained, the results were distributed by quintiles in each matrix, which allowed us to obtain five ranges equivalent to the levels of affectation for each indicator (very low, low, medium, high and very high). The quintiles were obtained by organizing the data from lowest to highest and dividing them into five equal parts (Vargas, 1995; Benjumea et al., 2006); in Excel, the formula "PERCENTIL.INC" was used to perform the calculation.

Affectations were estimated for 2040, 2070, and 2100 , according to the availability of data, and the greatest impacts are exposed as projected for the end of the century. In this respect, the work was based on the assumption that the variables will remain constant over time, since there is no official information available projected for these years. The number of inhabitants is the only variable estimated by DANE for 2020 (based on the 2005 population census), but it does not go beyond this, since there is a high probability of obtaining erroneous estimates. Finally, the data were analyzed and interpretative graphs were drawn up.

\section{RESULTS}

The socioeconomic impacts of climate change in the country's coastal municipalities were identified using a vulnerability analysis for the Colombian coastal zone, which served as an input to complement the Third National Communication on Climate Change (2017). Twenty-three indicators related to exposure (14), sensitivity (6) and adaptive capacity (3) were used within the dimensions of food security, human habitat, and infrastructure. Also, future scenarios were developed, projecting the impacts caused by SLR and coastal erosion threats on socioeconomic variables for 2040, 2070, and 2100 . 
que las variables se mantendrán constantes en el tiempo, pues no existe información oficial disponible proyectada a estos años; el número de habitantes es la única variable estimadas por el DANE para 2020 (basada en el censo poblacional de 2005) y no va más allá pues existe alta probabilidad de obtener estimaciones erradas. Y finalmente se analizaron los datos y se elaboraron gráficas interpretativas.
The results are presented according to threat, sensitivity, and adaptive capacity indicators respectively. For the former, the study presents the effects of SLR (Figure 3 and Figure 4) and coastal erosion (Figure 5 and Figure 6); for the sensitivity indicators, the intrinsic socioeconomic conditions of the study municipalities; and for the adaptive capacity, the levels of municipal productivity and the possibility that they have of investing to deal with climate change.
Tabla 1. Indicadores socioeconómicos para el análisis de vulnerabilidad al cambio climático en la zona costera e insular de Colombia.
Table 1. Socioeconomic indicators for the analysis of vulnerability to climate change in Colombia's coastal and insular zones.

\begin{tabular}{|c|c|c|c|c|c|c|c|c|c|}
\hline \multirow{3}{*}{$\begin{array}{l}\text { Componente } \\
\text { Component }\end{array}$} & \multicolumn{3}{|c|}{$\begin{array}{c}\text { Amenaza } \\
\text { Threat } \\
\end{array}$} & \multicolumn{3}{|c|}{$\begin{array}{l}\text { Sensibilidad } \\
\text { Sensitivity } \\
\end{array}$} & \multicolumn{3}{|c|}{$\begin{array}{l}\text { Capacidad Adaptativa } \\
\text { Adaptive capacity } \\
\end{array}$} \\
\hline & Indicador & Serie de datos & Fuente & Indicador & $\begin{array}{l}\text { Serie de } \\
\text { datos }\end{array}$ & Fuente & Indicador & $\begin{array}{c}\text { Serie de } \\
\text { datos }\end{array}$ & Fuente \\
\hline & Indicator & Data set & Source & Indicator & Data set & Source & Indicator & Data set & Source \\
\hline \multirow{2}{*}{$\begin{array}{l}\text { Seguridad } \\
\text { Alimentaria }\end{array}$} & \begin{tabular}{|c} 
\\
Áreas \\
agropecuarias \\
municipales \\
susceptibles de \\
inundaciones \\
por ANM \\
Municipal \\
agricultural areas \\
susceptible to \\
SLR flooding..
\end{tabular} & \begin{tabular}{|c|} 
Usos \\
agropecuarios: \\
$\mathbf{2 0 1 4}$ \\
ANM: $\mathbf{2 0 4 0}$ \\
$\mathbf{2 0 7 0 , 2 1 0 0}$ \\
\\
Agricultural \\
uses: 2014 \\
SLR: 2040 \\
2070, 2100
\end{tabular} & $\begin{array}{c}\text { UPRA } \\
\text { INVEMAR }\end{array}$ & \begin{tabular}{|c|} 
PIB agrícola \\
y pecuario de \\
los municipios \\
costeros (Miles \\
de millones de \\
pesos) respecto \\
al PIB de la \\
misma rama \\
departamental. \\
Agricultural \\
and livestock \\
GDP of coastal \\
municipalities \\
(Billions of \\
pesos) in relation \\
to the GDP \\
of the same \\
departmental \\
branch.
\end{tabular} & $2000-2014$ & DANE & \multirow{2}{*}{$\begin{array}{c}\text { Inversión en } \\
\text { ambiente y } \\
\text { desarrollo } \\
\text { sostenible } \\
\text { para } \\
\text { municipios } \\
\text { costeros } \\
\\
\text { Investment in } \\
\text { environment } \\
\text { and } \\
\text { sustainable } \\
\text { development } \\
\text { for coastal } \\
\text { municipalities }\end{array}$} & \multirow{2}{*}{$\begin{array}{l}2012- \\
2014\end{array}$} & \multirow{2}{*}{$\begin{array}{c}\text { Sistema } \\
\text { General de } \\
\text { Regalías } \\
\text { (SGR) } \\
\\
\\
\text { General } \\
\text { Royalty } \\
\text { System (GRS) }\end{array}$} \\
\hline & \begin{tabular}{|c} 
Áreas \\
agropecuarias \\
municipales \\
afectadas por \\
erosión costera. \\
\\
Municipal \\
agricultural \\
areas affected by \\
coastal erosion.
\end{tabular} & \begin{tabular}{|c|} 
Usos \\
agropecuarios: \\
$\mathbf{2 0 1 4}$ \\
erosión \\
costera: 2040, \\
$\mathbf{2 0 7 0 , 2 1 0 1}$ \\
\\
Agricultural \\
uses: 2014 \\
coastal erosion: \\
2040, 2070, \\
2101
\end{tabular} & $\begin{array}{c}\text { UPRA } \\
\text { INVEMAR }\end{array}$ & \begin{tabular}{|c|} 
Nivel de aporte \\
PIB pesca \\
municipal \\
al PIB \\
departamental. \\
Level of \\
contribution \\
from municipal \\
fishing GDP to \\
departmental \\
GDP
\end{tabular} & $2000-2014$ & DANE & & & \\
\hline
\end{tabular}




\begin{tabular}{|c|c|c|c|c|c|c|c|c|c|}
\hline \multirow{2}{*}{$\begin{array}{l}\text { Componente } \\
\text { Component }\end{array}$} & \multicolumn{3}{|c|}{$\begin{array}{l}\text { Amenaza } \\
\text { Threat }\end{array}$} & \multicolumn{3}{|c|}{$\begin{array}{l}\text { Sensibilidad } \\
\text { Sensitivity }\end{array}$} & \multicolumn{3}{|c|}{$\begin{array}{l}\text { Capacidad Adaptativa } \\
\text { Adaptive capacity }\end{array}$} \\
\hline & $\begin{array}{l}\text { Indicador } \\
\text { Indicator }\end{array}$ & $\begin{array}{c}\text { Serie de datos } \\
\text { Data set }\end{array}$ & $\begin{array}{l}\text { Fuente } \\
\text { Source }\end{array}$ & $\begin{array}{l}\text { Indicador } \\
\text { Indicator }\end{array}$ & $\begin{array}{c}\begin{array}{c}\text { Serie de } \\
\text { datos }\end{array} \\
\text { Data set }\end{array}$ & $\begin{array}{l}\text { Fuente } \\
\text { Source }\end{array}$ & $\begin{array}{l}\text { Indicador } \\
\text { Indicator }\end{array}$ & $\begin{array}{c}\text { Serie de } \\
\text { datos } \\
\text { Data set }\end{array}$ & $\begin{array}{l}\text { Fuente } \\
\text { Source }\end{array}$ \\
\hline \multirow{6}{*}{$\begin{array}{c}\text { Hábitat } \\
\text { Humano } \\
\\
\text { Human } \\
\text { Habitat }\end{array}$} & $\begin{array}{l}\text { Área municipal } \\
\text { afectada por } \\
\text { ANM. } \\
\text { Municipal area } \\
\text { affected by SLRw }\end{array}$ & 2014 & IGAC & \multirow{4}{*}{$\begin{array}{c}\text { Nivel de NBI } \\
\text { por municipio } \\
\text { Level of UBN } \\
\text { per municipality }\end{array}$} & \multirow{4}{*}{2005} & \multirow{4}{*}{ DANE } & \multirow{4}{*}{$\begin{array}{c}\text { Inversión en } \\
\text { ambiente y } \\
\text { desarrollo } \\
\text { sostenible } \\
\text { para } \\
\text { municipios } \\
\text { costeros } \\
\\
\text { Investment in } \\
\text { environment } \\
\text { and } \\
\text { sustainable } \\
\text { development } \\
\text { for coastal } \\
\text { municipalities }\end{array}$} & \multirow{4}{*}{$\begin{array}{l}2012- \\
2014\end{array}$} & \multirow{4}{*}{$\begin{array}{c}\text { Sistema } \\
\text { General de } \\
\text { Regalías } \\
\text { (SGR) } \\
\\
\\
\text { General } \\
\text { Royalty } \\
\text { System (GRS) }\end{array}$} \\
\hline & $\begin{array}{c}\begin{array}{c}\text { Área municipal } \\
\text { afectada por } \\
\text { erosión costera. }\end{array} \\
\text { Municipal area } \\
\text { affected by } \\
\text { coastal erosion. }\end{array}$ & 2014 & IGAC & & & & & & \\
\hline & $\begin{array}{c}\begin{array}{c}\text { Población } \\
\text { afectada por } \\
\text { ANM. }\end{array} \\
\text { Population } \\
\text { affected by SLR. }\end{array}$ & $1985-2010$ & DANE & & & & & & \\
\hline & $\begin{array}{c}\begin{array}{c}\text { Población } \\
\text { afectada por } \\
\text { erosión costera }\end{array} \\
\begin{array}{c}\text { Population } \\
\text { affected by } \\
\text { coastal erosion }\end{array}\end{array}$ & $1985-2020$ & DANE & & & & & & \\
\hline & \begin{tabular}{|c} 
Áreas de \\
desarrollo \\
turístico \\
susceptibles de \\
inundación por \\
ANM \\
Tourist \\
development \\
areas susceptible \\
to SLR flooding.
\end{tabular} & 2014 & $\begin{array}{c}\text { UPRA } \\
\text { INVEMAR }\end{array}$ & \multirow{2}{*}{$\begin{array}{c}\text { Nivel de aporte } \\
\text { del PIB turismo } \\
\text { municipal } \\
\text { al PIB } \\
\text { departamental } \\
\text { Level of } \\
\text { contribution } \\
\text { from municipal } \\
\text { tourism GDP } \\
\text { to departmental } \\
\text { GDP }\end{array}$} & \multirow{2}{*}{$2000-2014$} & \multirow{2}{*}{ DANE } & \multirow{2}{*}{$\begin{array}{c}\text { Nivel de } \\
\text { importancia } \\
\text { económica } \\
\text { municipal } \\
\\
\text { Level of } \\
\text { municipal } \\
\text { economic } \\
\text { importance }\end{array}$} & \multirow{2}{*}{$\begin{array}{l}2013- \\
2014\end{array}$} & \multirow{2}{*}{ DANE } \\
\hline & 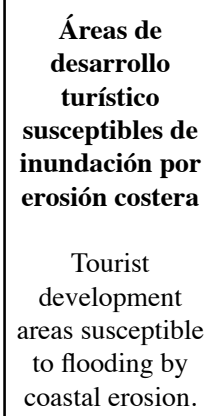 & 2014 & $\begin{array}{c}\text { UPRA } \\
\text { INVEMAR }\end{array}$ & & & & & & \\
\hline
\end{tabular}




\begin{tabular}{|c|c|c|c|c|c|c|c|c|c|}
\hline Componente & & $\begin{array}{c}\text { Amenaza } \\
\text { Threat }\end{array}$ & & & $\begin{array}{l}\text { sibilidad } \\
\text { nsitivity }\end{array}$ & & $\begin{array}{r}\text { Capac } \\
\text { Ada }\end{array}$ & $\begin{array}{l}\text { idad Ada| } \\
\text { ptive capa }\end{array}$ & ptativa \\
\hline Component & $\begin{array}{l}\text { Indicador } \\
\text { Indicator }\end{array}$ & $\begin{array}{c}\text { Serie de datos } \\
\text { Data set }\end{array}$ & $\begin{array}{l}\text { Fuente } \\
\text { Source }\end{array}$ & $\begin{array}{l}\text { Indicador } \\
\text { Indicator }\end{array}$ & $\begin{array}{c}\begin{array}{c}\text { Serie de } \\
\text { datos }\end{array} \\
\text { Data set }\end{array}$ & $\begin{array}{l}\text { Fuente } \\
\text { Source }\end{array}$ & $\begin{array}{l}\text { Indicador } \\
\text { Indicator }\end{array}$ & \begin{tabular}{|c|}
$\begin{array}{c}\text { Serie de } \\
\text { datos }\end{array}$ \\
Data set
\end{tabular} & $\begin{array}{l}\text { Fuente } \\
\text { Source }\end{array}$ \\
\hline \multirow[t]{2}{*}{$\begin{array}{l}\text { Hábitat } \\
\text { Humano }\end{array}$} & $\begin{array}{c}\begin{array}{c}\text { Número de } \\
\text { viviendas } \\
\text { afectadas por } \\
\text { ANM. }\end{array} \\
\text { Number of } \\
\text { households } \\
\text { affected by SLR. }\end{array}$ & CENSO 2005 & DANE & \multirow{2}{*}{$\begin{array}{c}\text { Nivel de } \\
\text { deficiencia } \\
\text { de materiales } \\
\text { constitutivos de } \\
\text { las viviendas } \\
\text { municipales } \\
\text { Level of } \\
\text { deficiency of } \\
\text { materials used } \\
\text { in municipal } \\
\text { housing }\end{array}$} & \multirow{2}{*}{2005} & \multirow{2}{*}{ DANE } & \multirow{2}{*}{$\begin{array}{c}\text { Nivel de } \\
\text { importancia } \\
\text { económica } \\
\text { municipal }\end{array}$} & \multirow{2}{*}{$\begin{array}{l}2013- \\
2014\end{array}$} & \multirow{2}{*}{ DANE } \\
\hline & $\begin{array}{c}\begin{array}{c}\text { Viviendas } \\
\text { afectadas por } \\
\text { erosión costera. }\end{array} \\
\text { Households } \\
\text { affected by } \\
\text { coastal erosion. }\end{array}$ & CENSO 2006 & DANE & & & & & & \\
\hline \multirow{4}{*}{$\begin{array}{c}\text { Infraestructura } \\
\text { Infraestructure }\end{array}$} & $\begin{array}{l}\text { Vías inundadas } \\
\text { por ANM. } \\
\text { Roads flooded by } \\
\text { SLR. }\end{array}$ & 2015 & $\begin{array}{c}\text { Ministerio de } \\
\text { Transporte } \\
\text { Ministry of } \\
\text { Transport }\end{array}$ & \multirow{4}{*}{$\begin{array}{c}\text { Nivel de } \\
\text { aporte del PIB } \\
\text { transporte } \\
\text { municipal } \\
\text { al PIB } \\
\text { departamental } \\
\text { Level of } \\
\text { contribution } \\
\text { from municipal } \\
\text { transport GDP } \\
\text { to departmental } \\
\text { GDP }\end{array}$} & \multirow{4}{*}{$2000-2014$} & \multirow{4}{*}{ DANE } & \multirow{4}{*}{$\begin{array}{c}\text { Valor de la } \\
\text { inversión } \\
\text { nacional en } \\
\text { las zonas } \\
\text { portuarias } \\
\text { costeras. } \\
\text { Value of } \\
\text { national } \\
\text { investment in } \\
\text { coastal port } \\
\text { areas. }\end{array}$} & \multirow{4}{*}{$\begin{array}{l}2011- \\
2015\end{array}$} & \multirow{4}{*}{$\begin{array}{c}\begin{array}{c}\text { Superinten- } \\
\text { dencia de } \\
\text { puertos y }\end{array} \\
\text { Transporte } \\
\text { Superinten- } \\
\text { dence of Ports } \\
\text { and Transport }\end{array}$} \\
\hline & $\begin{array}{c}\begin{array}{c}\text { Vías afectadas } \\
\text { por erosión } \\
\text { costera }\end{array} \\
\text { Roads affected by } \\
\text { coastal erosion }\end{array}$ & 2015 & $\begin{array}{c}\text { Ministerio de } \\
\text { Transporte } \\
\text { Ministry of } \\
\text { Transport }\end{array}$ & & & & & & \\
\hline & $\begin{array}{c}\text { Zona portuaria } \\
\text { susceptible de } \\
\text { inundación por } \\
\text { ANM. } \\
\text { Port area } \\
\text { susceptible to } \\
\text { flooding by SLR. }\end{array}$ & 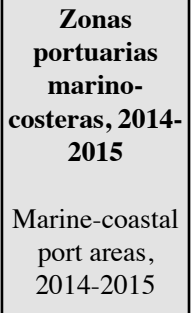 & $\begin{array}{c}\text { INVEMAR } \\
\text { Superpuertos } \\
\text { INVEMAR/ } \\
\text { Superports }\end{array}$ & & & & & & \\
\hline & $\begin{array}{c}\begin{array}{c}\text { Zona portuaria } \\
\text { afectada por } \\
\text { erosión costera }\end{array} \\
\text { Port area affected } \\
\text { by coastal erosion }\end{array}$ & \begin{tabular}{|c|} 
Zonas \\
portuarias \\
marino- \\
costeras, 2014- \\
$\mathbf{2 0 1 5}$ \\
\\
Marine-coastal \\
port areas, \\
2014-2015
\end{tabular} & $\begin{array}{c}\text { INVEMAR } \\
\text { Superpuertos } \\
\text { INVEMAR/ } \\
\text { Superports }\end{array}$ & & & & & & \\
\hline
\end{tabular}




\section{RESULTADOS}

Los impactos socioeconómicos del cambio climático en los municipios costeros del país se identificaron mediante la elaboración de un análisis de vulnerabilidad para la zona costera colombiana, el cual sirvió de insumo para complementar la Tercera Comunicación Nacional de Cambio Climático (2017). Es así como se emplearon 23 indicadores entre exposición (14), sensibilidad (6) y capacidad adaptativa (3) dentro de las dimensiones de seguridad alimentaria, hábitat humano e infraestructura. Así mismo, se elaboraron los escenarios futuros para los años 2040, 2070 y 2100, donde se proyectaron los impactos causados por las amenazas de ANM y erosión costera sobre las variables socioeconómicas.

Los resultados se exponen de acuerdo con los indicadores de amenaza, sensibilidad y capacidad adaptativa respectivamente. Para los primeros, se muestran las afectaciones del ANM (Figuras 3 y 4) y erosión costera (Figuras 5 y 6); en los de sensibilidad se presentan las condiciones socioeconómicas intrínsecas de los municipios de estudio; y en la capacidad adaptativa, los niveles de productividad municipal y la posibilidad que tienen de invertir para hacer frente al cambio climático.

Es así como, los resultados indicaron que los municipios pertenecientes a la zona costera de Colombia sufrirán los impactos del cambio climático debido a las amenazas de ANM y erosión costera. Las máximas afectaciones serán hacia 2100, pues se espera el mayor incremento del nivel del mar en $40 \mathrm{~cm}$.

\section{Indicadores de amenaza}

Los indicadores de amenaza en la dimensión de hábitat humano muestran que hacia 2100 se inundaría $9 \%$ de las áreas municipales, es decir, cerca de 640.000 hectáreas, lo cual afectaría a $5 \%$ de la población y $4,3 \%$ del total de las viviendas ubicadas en esta zona. Los municipios de la región Pacífico tienen niveles de afectación muy altos, donde sobresalen Guapi, Mosquera (Cauca) y La Tola (Nariño); y en la región Caribe estos niveles son altos, principalmente en los municipios de Remolino, Sitio Nuevo y Pueblo Viejo (Magdalena). Por otro lado, la erosión costera tendría efectos negativos en cerca de $3,4 \%$ de la población total costera, especialmente en la región Caribe con 3,71\% (nivel alto de afectación) y $0,89 \%$ de las viviendas en ambas regiones (nivel alto). Así mismo, el turismo tendría pérdidas en las
Thus, the results indicated that the municipalities belonging to Colombia's coastal zone will suffer the impacts of climate change due to threats of SLR and coastal erosion. The maximum effects will occur around 2100, when the greatest increase in sea level -of $40 \mathrm{~cm}$ - is expected.

\section{Threat indicators}

Threat indicators for the human habitats dimension show that by $2100,9 \%$ of municipal areas will be flooded; i.e., close to 640,000 hectares, which will affect $5 \%$ of the population and $4.3 \%$ of the total houses located in this area. The municipalities of the Pacific region show very high levels of affectation, with Guapi, Mosquera (Cauca) and La Tola (Nariño) being the most affected. In the Caribbean region, these levels are high, mainly in the municipalities of Remolino, Sitio Nuevo and Pueblo Viejo (Madalena). On the other hand, coastal erosion will have negative effects on about $3.4 \%$ of the total coastal population, especially in the Caribbean region with $3.71 \%$ (high level of affectation) and $0.89 \%$ of housing in both regions (high level). Likewise, tourism will suffer losses in the areas where this activity is developed of $0.27 \%$ by SLR and $13 \%$ by coastal erosion, where the Pacific region stands out with $16.4 \%$ loss by the latter.

In the dimension of food security, the implications for agricultural activity involve floods that are expected in $1.2 \%$ of the areas destined for this use due to SLR and losses of $0.11 \%$ due to coastal erosion, with low levels of affectation.

Road and port infrastructure will also suffer damage, with $5.95 \%$ of the total port area and $12.4 \%$ of the total number of highways subject to flooding mainly affecting the ports of Tumaco and Buenaventura in the Pacific region (high level) and roads in the municipalities of Pueblo Viejo, Sitio Nuevo and Ciénaga mainly (medium level). While coastal erosion will lead to the loss of $2.4 \%$ of the port areas and $2.57 \%$ of the roads, for the Caribbean, the level of affectation is high, especially in the port areas of Necoclí, Turbo (Antioquia), and Barranquilla.

\section{Sensitivity indicators}

In the human habitat dimension, poverty was measured through the Unsatisfied Basic Needs (UBN) indicator, resulting in $44 \%$ of coastal municipalities being in a critical level of deprivation. The total of municipalities presents a UBN of $78 \%$, with the following outstanding figures: Uribia in La Guajira (96.0\%), La Tola in Nariño 


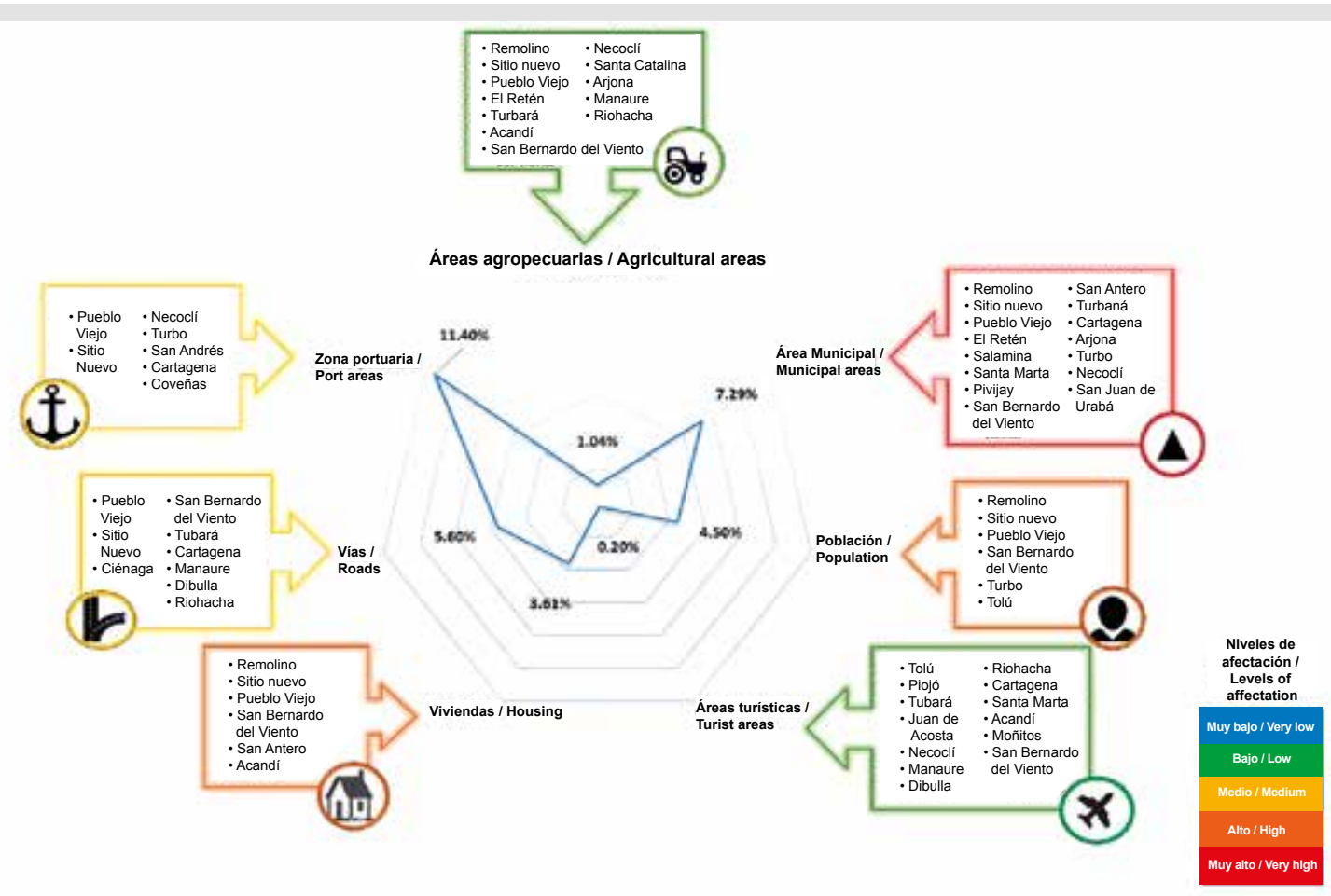

Figura 3. Niveles de afectación municipal por ANM al año 2100 para los indicadores socioeconómicos en la región Caribe.
Figure 3. Levels of municipal affectation by SLR to the year 2100 for socioeconomic indicators in the Caribbean region.

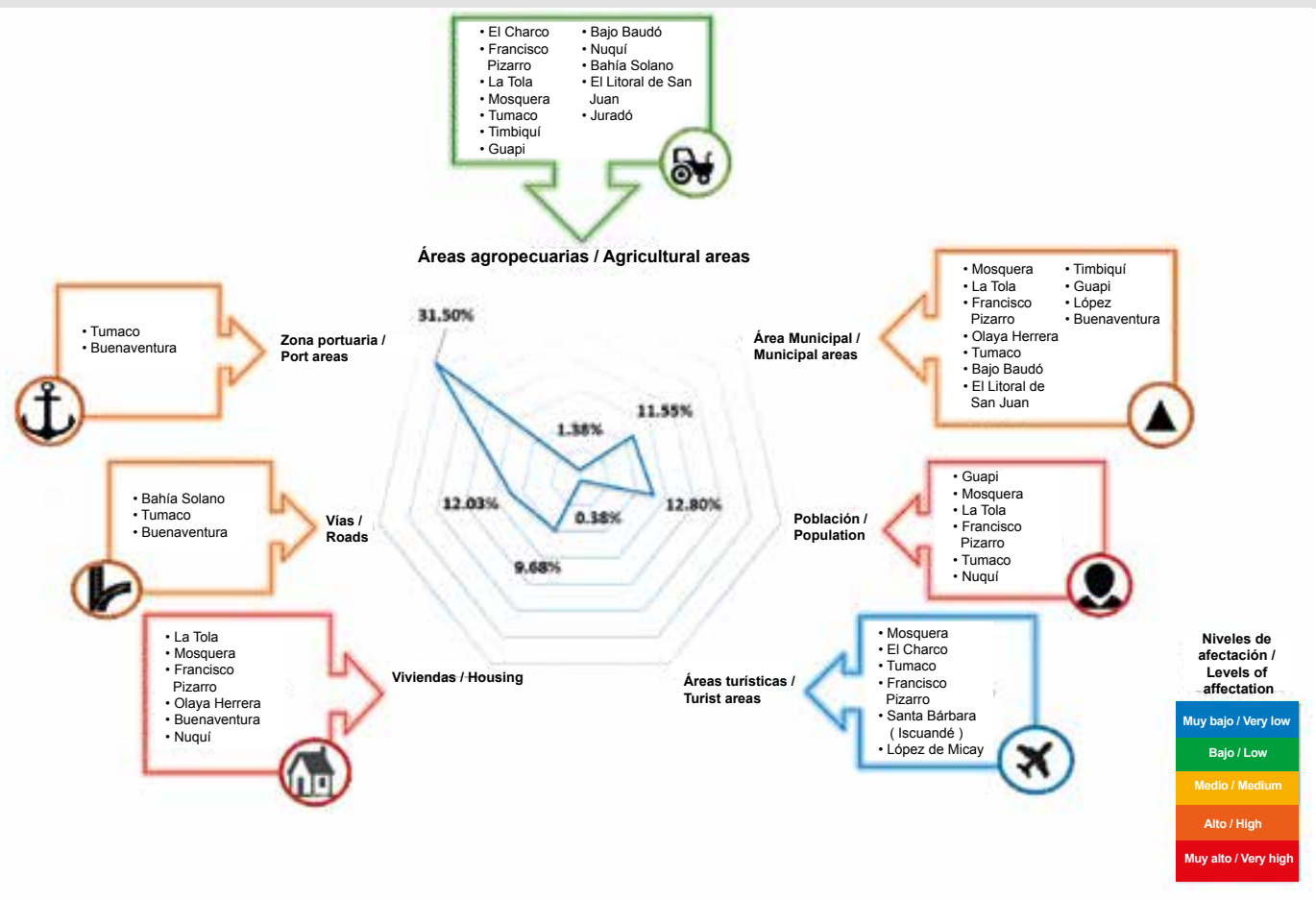

Figura 4. Niveles de afectación municipal por ANM al año 2100 para los indicadores socioeconómicos en la región Pacifico.
Figure 4. Levels of municipal affectation by SLR to the year 2100 for socioeconomic indicators in the Pacific region 


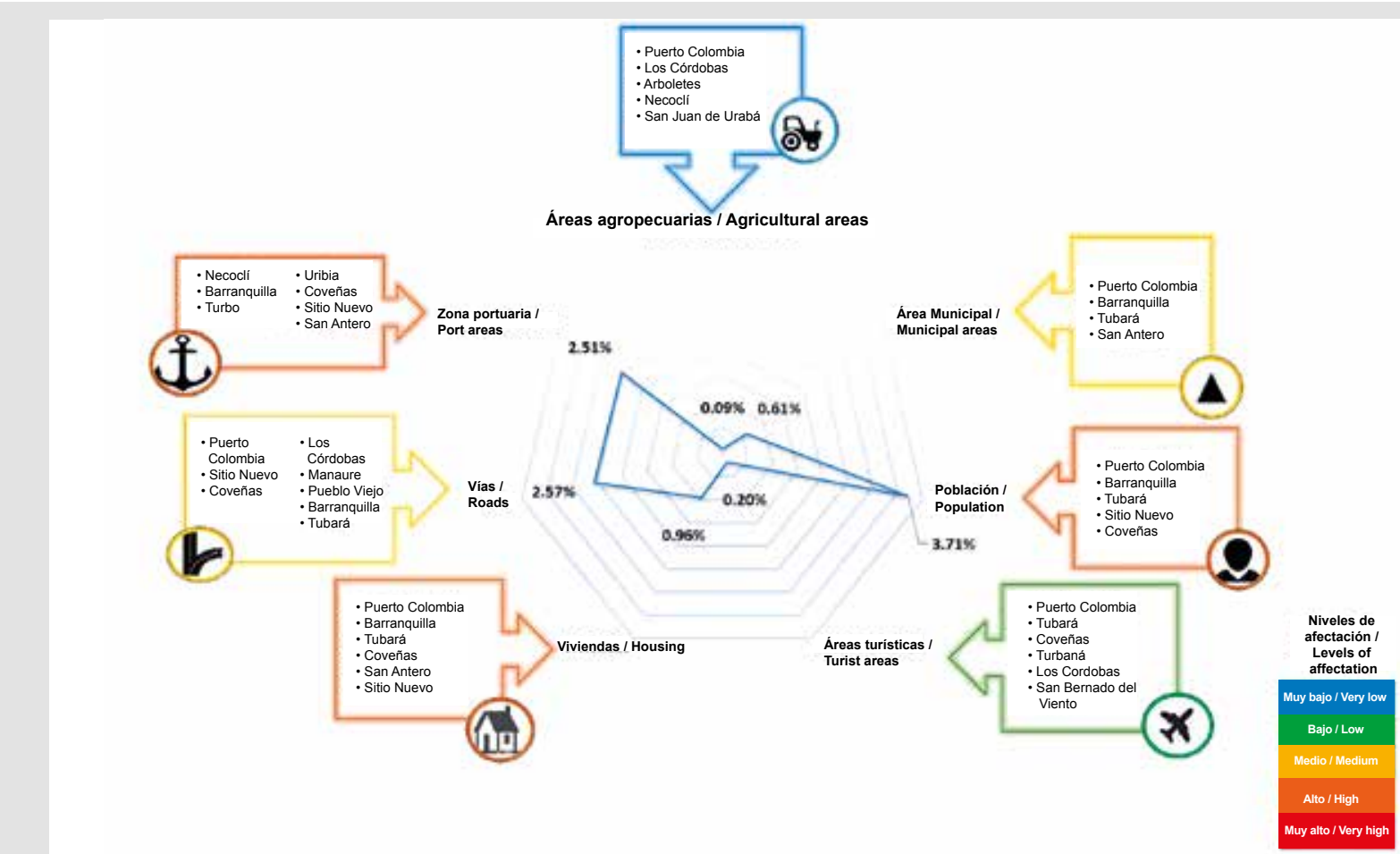

Figura 5. Niveles de afectación municipal por erosión costera al año 2100 para los indicadores socioeconómicos en la región Caribe.
Figure 5. Levels of municipal affectation by coastal erosion by year 2100 for socioeconomic indicators in the Caribbean region.

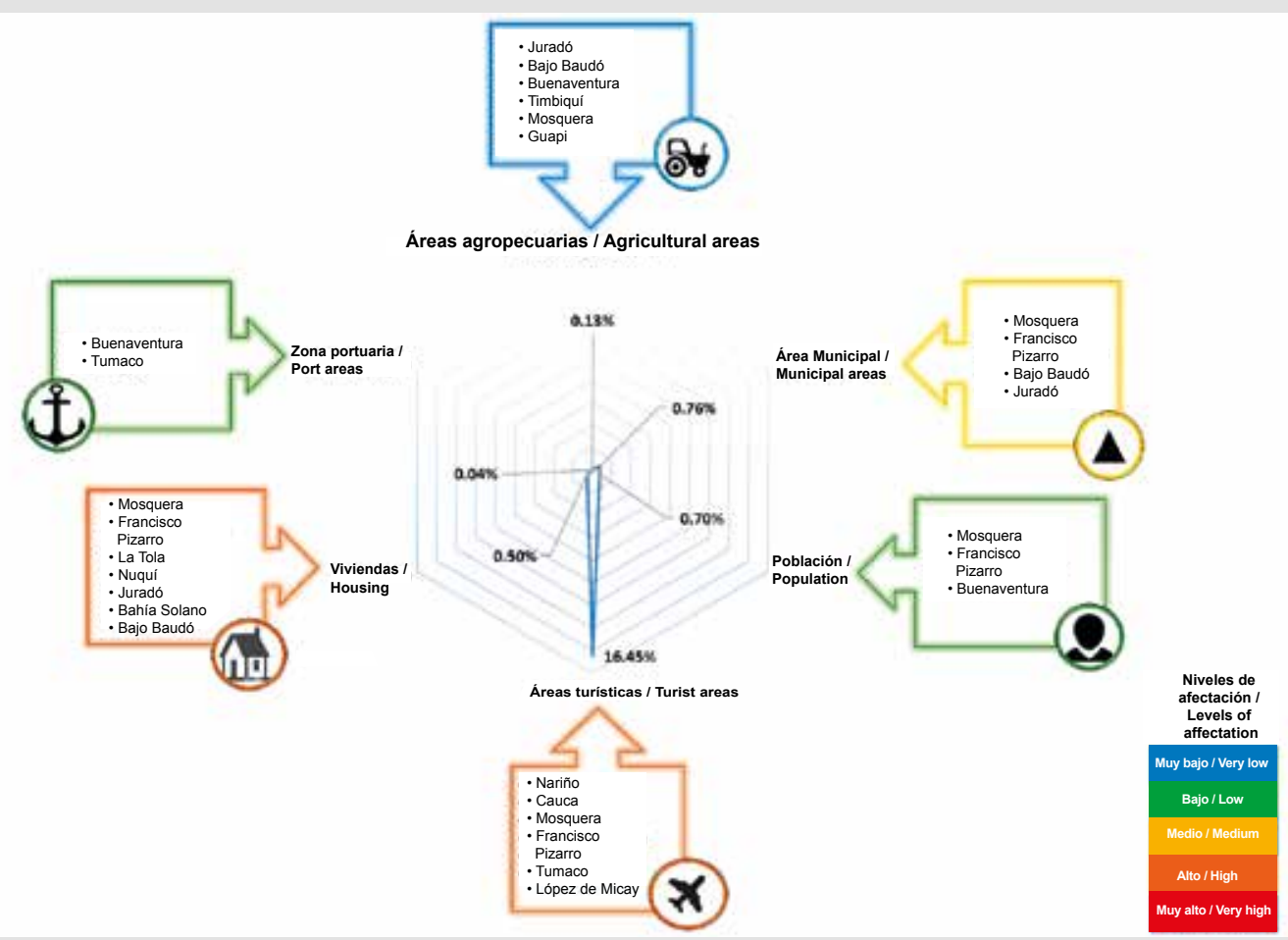

Figura 6. Niveles de afectación municipal por erosión costera al año 2100 para los indicadores socioeconómicos en la región Pacífico.
Figure 6. Levels of municipal affectation by coastal erosion by year 2100 for socioeconomic indicators in the Pacific region. 
áreas de desarrollo de esta actividad en 0,27\% por ANM y $13 \%$ por erosión costera, donde resalta la región Pacífico con $16,4 \%$ de pérdida por esta última. En la dimensión de seguridad alimentaria, la actividad agropecuaria tendría implicaciones, se esperan inundaciones en 1,2\% de las áreas destinadas a este uso debido al ANM y pérdidas de $0,11 \%$ por erosión costera, con niveles bajos de afectación.

$\mathrm{La}$ infraestructura vial y portuaria también presentarían impactos, se inundaría 5,95\% del área total de zonas portuarias y $12,4 \%$ del total de carreteras, afectando principalmente los puertos de Tumaco y Buenaventura en la región Pacífico (nivel alto) y vías en los municipios de Pueblo Viejo, Sitio Nuevo y Ciénaga principalmente (nivel medio). Mientras que por erosión costera se perdería 2,4\% de las zonas portuarias y $2,57 \%$ de las vías; para el Caribe su nivel de afectación es alto especialmente en las zonas portuarias de Necoclí, Turbo (Antioquia) y Barranquilla.

\section{Indicadores de sensibilidad}

En la dimensión de hábitat humano, la pobreza se midió a través del indicador de Necesidades Básicas Insatisfechas (NBI), resultando $44 \%$ de los municipios costeros en un nivel crítico de carencias; el total de los municipios tiene un NBI de 78\%, sobresaliendo Uribia (96.0\%) en La Guajira, La Tola (91.5\%) de Nariño, Guapi (87.4\%) del Cauca y Juradó (86.2\%) de Chocó. A su vez, la deficiencia en viviendas indica que 44 de los 60 municipios tienen déficits en los materiales constitutivos de las viviendas; destaca Mosquera (94\%), El Charco (91\%) y Olaya Herrera (90\%) de Nariño. Así mismo, se estima que 24 de los 60 municipios costeros agrupan $93,8 \%$ del PIB turístico, siendo Cartagena, Barranquilla, Santa Marta y San Andrés los municipios sobresalientes.

En cuanto a la dimensión de seguridad alimentaria, la rama agropecuaria concentra 12 municipios con alta dependencia económica a esta actividad, pues solo entre ellos aportan cerca de $63 \%$ de este PIB, sobresaliendo Buenaventura (Valle del Cauca), Tumaco (Nariño) y Piviajay (Magdalena). Por su parte, 17 municipios concentran aproximadamente 92\% del PIB pesquero figurando nuevamente Buenaventura, Tumaco y Cartagena (Bolívar). Para la dimensión de infraestructura, por su parte, se encontró que en la rama de transporte 12 municipios suman 96\% del aporte a este PIB, resaltando Barranquilla, Cartagena, Soledad y Santa Marta.
(91.5\%), Guapi in Cauca (87.4\%), and Juradó in Chocó $(86.2 \%)$. In turn, the housing deficiency indicates that 44 of the 60 municipalities have deficits in building materials, with Mosquera (94\%), El Charco (91\%) and Olaya Herrera (90\%) in Nariño being the most significant. It is also estimated that 24 of the 60 coastal municipalities account for 93.8\% of tourism GDP, with Cartagena, Barranquilla, Santa Marta and San Andrés as the outstanding municipalities.

In terms of food security, the agricultural branch concentrates 12 municipalities with high economic dependence on this activity, as between them they contribute about $63 \%$ of this GDP, with Buenaventura (Valle del Cauca), Tumaco (Nariño) and Pivijay (Magdalena) standing out. On the other hand, 17 municipalities concentrate approximately $92 \%$ of the fishing GDP, with Buenaventura, Tumaco and Cartagena (Bolívar) appearing again. For the infrastructure dimension on the other hand, it was found that in the transport branch 12 municipalities contribute $96 \%$ to this GDP, highlighting Barranquilla, Cartagena, Soledad and Santa Marta.

\section{Adaptive capacity indicators}

In the human habitat dimension, the Municipal Economic Importance indicator (DANE, 2012) shows that $28 \%$ of coastal municipalities present very high and high levels of importance, with Barranquilla and Cartagena standing out, while $65 \%$ of them are at low levels of importance (Figure 7). The investment in environment and sustainable development made through the General System of Royalties (SGR) indicates that 40 of the 60 municipalities of study do not report investment in this sector; $3.6 \%$ of the budget is allocated at national level to this item. The coastal zone perceives $26 \%$ of the resources, of which the Caribbean region accounted for almost all (99\%), while the Pacific region participated with $0.17 \%$ (Figure 8).

Port activity in Colombia presents investments in maintenance and in the infrastructure of the port areas. The highest levels of investment are found in Cartagena, Buenaventura, Uribia and Santa Marta, located in a range between of US\$ 55,000 and US\$220,000 million per year (Figure 9)

\section{DISCUSSION}

In terms of infrastructure, a possible affectation of $5.9 \%$ of the total maritime port zones is highlighted 
Indicadores de capacidad adaptativa

En la dimensión de hábitat humano, el indicador de Importancia Económica Municipal (DANE, 2012) muestra que $28 \%$ de los municipios costeros tienen niveles muy alto y alto de importancia, sobresaliendo Barranquilla y Cartagena; mientras que $65 \%$ de los mismos se ubican niveles bajos (Figura 7). La inversión en ambiente y desarrollo sostenible realizada mediante el Sistema General de Regalías (SGR) indica que 40 de los 60 municipios de estudio no registran inversión en este sector; se destina a nivel nacional 3,6\% del presupuesto a este rubro. la zona costera percibe $26 \%$ de los recursos, del cual a la región Caribe le correspondió casi la totalidad (99\%), mientras que la región Pacífico participó con 0,17\% (Figura 8).

La actividad portuaria en Colombia presenta inversiones en mantenimiento y en la infraestructura de las zonas portuarias; Los mayores niveles de inversión se encuentran en Cartagena, Buenaventura, Uribia y Santa Marta, ubicados en un ámbito entre US\$ 55 mil y US\$ 220 mil millones al año (Figura 9).

\section{DISCUSIÓN}

El análisis a escala municipal de este trabajo no tiene precedentes en la zona marino-costera de Colombia, el cual permitió conocer los impactos del cambio climático a nivel local al evidenciar las condiciones particulares de los territorios. Es así como se identificaron posibles impactos ocasionados por el cambio climático en los elementos socioeconómicos de los municipios ubicado en las regiones Caribe, Pacífico e Insular de Colombia a causa de las dos principales amenazas para esta zona correspondientes al ANM y la erosión costera. La pertinencia del ejercicio se constituye en un insumo para la planificación territorial, así como para la formulación de los planes municipales integrales de gestión del cambio climático, dando cumplimiento a la Ley 1931 de 2018 "Por la cual se establecen directrices para la gestión del cambio climático".

La metodología utilizada, permitió acercar e integrar los posibles impactos sobre algunos elementos sociales y económicos enmarcados en las dimensiones de seguridad alimentaria, hábitat humano e infraestructura y medir los niveles de amenaza, sensibilidad y capacidad adaptativa ante el cambio climático. Con esto, fue posible tener una visión general del panorama local en cuanto a las debilidades y potencialidades de los municipios, ofreciendo así insumos para el direccionamiento de la gestión ante el cambio climático costero en el país. due to floods by SLR, mainly the ports of Tumaco and Buenaventura in the Pacific region. The municipal scale analysis of this work is unprecedented in Colombia's coastal marine zone, and it allowed us to determine the impacts of climate change at local level by highlighting the unique conditions of the territories. Thus, possible impacts caused by climate change were identified in the socioeconomic elements of municipalities located in the Caribbean, Pacific, and insular regions of Colombia, due to the two main threats for this zone: SLR and coastal erosion. The exercise constitutes an input for territorial planning, as well as for the formulation of comprehensive municipal plans for climate change management, in compliance with Law 1931 of 2018 "By which guidelines for climate change management are established."

The methodology used made it possible to approach and integrate the possible impacts on some social and economic elements framed in the dimensions of food security, human habitat and infrastructure and to measure the levels of threat, sensitivity and adaptive capacity in the face of climate change. With this, it was possible to obtain an overview of the local panorama in terms of the weaknesses and potentialities of the municipalities, thus offering inputs for the management of coastal climate change in the country.

The results obtained show similarities with international studies on climate change in coastal areas. The Colombian coastal municipalities showed possible impacts on human habitats especially on populations and productive activities with high economic dependence such as tourism, as estimated for Venezuela, Uruguay, and Peru (Tejeda, 2018; Nagy et al., 2019).

Results highlight the predictions on the impacts on coastal populations, indicating that by $2100,5 \%$ of these could be affected due to floods caused by the SLR and 3.4\% by coastal erosion. In this sense, even if just one person is harmed or loses his life by these threats, this should be considered as relevant. Likewise, there may be repercussions on municipalities with higher levels of poverty, such as Uribia (La Guajira), La Tola (Nariño), Guapi (Cauca) and Juradó (Chocó). This result, in turn, shows a 1\% increase with respect to previous National Communications on Climate Change (IDEAM-UNDP, 2001, 2010), which may reflect differences in the refinement of the analysis at municipal level compared to previous studies carried out on a larger scale.

High levels of poverty (78\% UBN) in the country's coastal municipalities, combined with low 

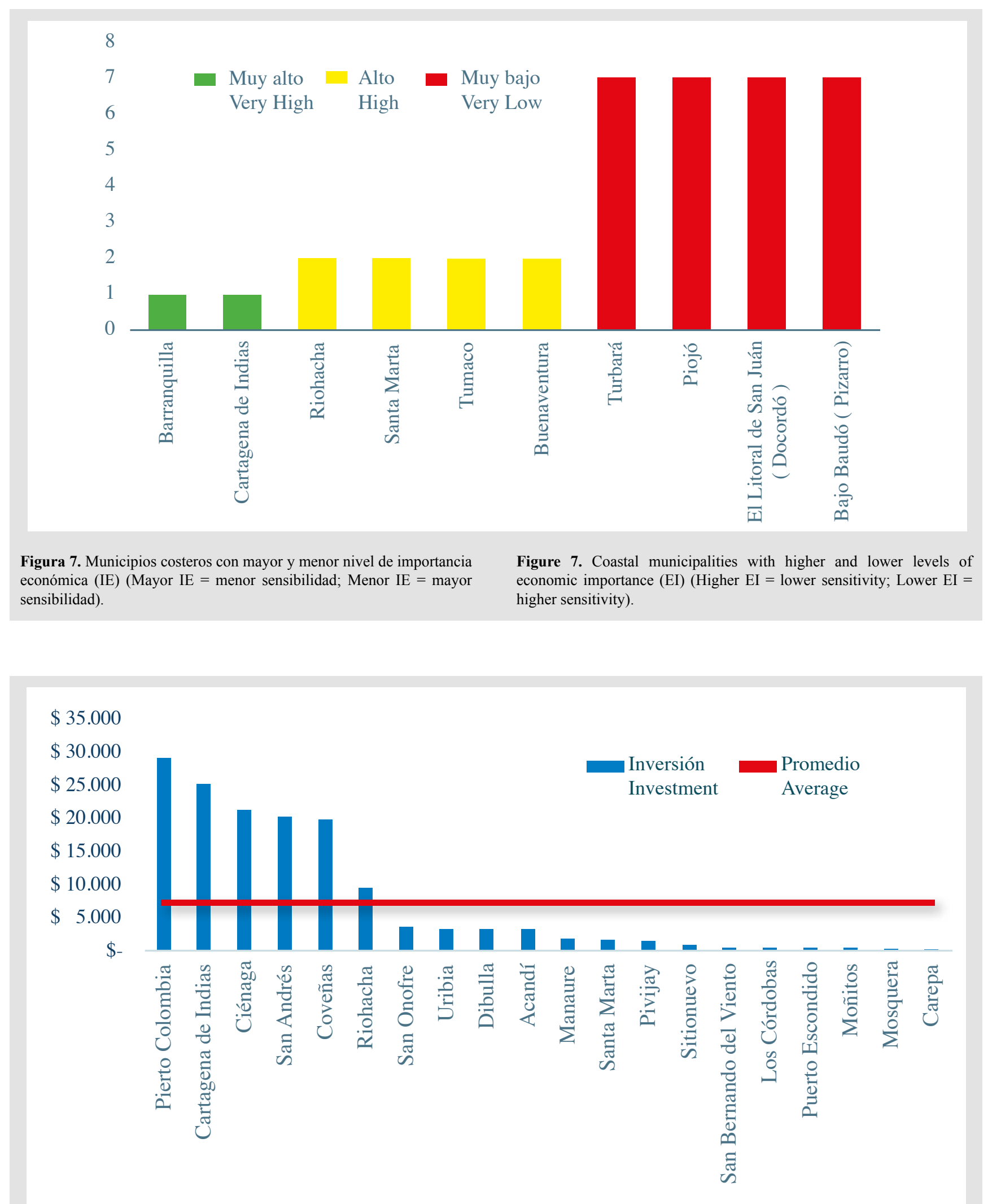

Figura 8. Inversión en ambiente y desarrollo sostenible municipal vs promedio municipal en miles de millones de pesos.
Figure 8. Investment in environment and municipal sustainable development vs. municipal average in billions of pesos. 


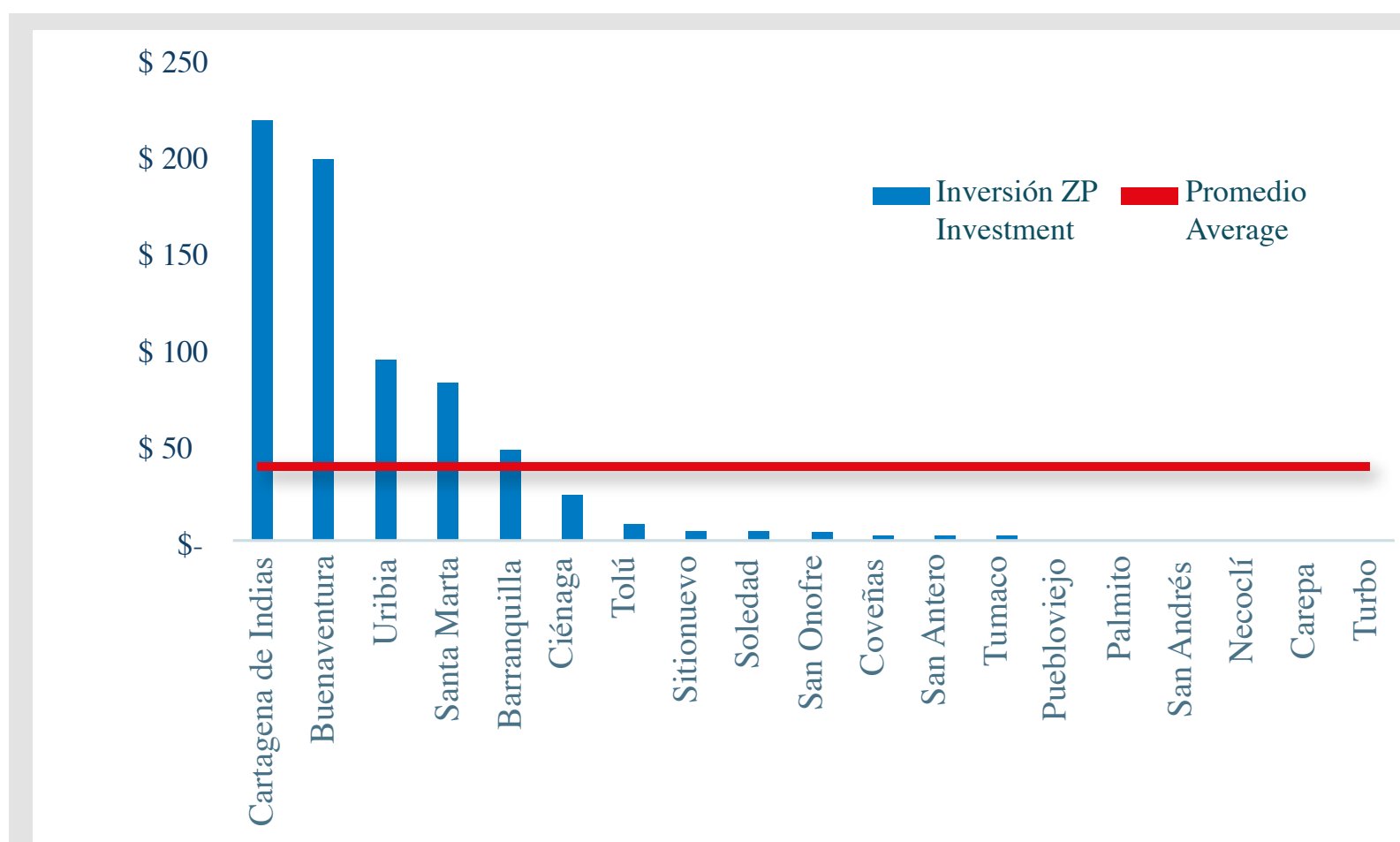

Figura 9. Niveles de inversión en zonas portuarias municipios vs media municipal en millones de pesos.
Figure 9. Levels of investment in municipal port areas vs municipal average in millions of pesos.
Los resultados obtenidos presentan similitudes con estudios internacionales sobre el cambio climático en las zonas costeras. Los municipios costeros colombianos mostraron posibles impactos en los hábitats humanos especialmente sobre las poblaciones y las actividades productivas con alta dependencia económica como el turismo, tal como se estimó para los países de Venezuela, Uruguay y Perú (Tejeda, 2018; Nagy et al., 2019).

Dentro de los resultados, se resaltan las predicciones sobre los impactos en las poblaciones costeras, donde al año $2100,5 \%$ de estas podrían verse afectadas debido a inundaciones causadas por el ANM y 3,4\% por erosión costera; en este sentido, al menos una persona que se vea perjudicada o pierda su vida por estas amenazas debe tomarse como un hecho relevante; así mismo, puede haber incidencias sobre los municipios con mayores niveles de pobreza como Uribia (La Guajira), La Tola (Nariño), Guapi (Cauca) y Juradó (Chocó). Este resultado encuentra a su vez, un incremento de $1 \%$ con respecto a las anteriores comunicaciones nacionales de cambio climático (IDEAM-PNUD, 2001, 2010), lo cual puede estar reflejando las diferencias en la afinación del análisis a nivel municipal frente a los estudios anteriores realizados a una mayor escala. levels of municipal economic importance, could increase vulnerability to climate change (Musetta et al., 2017; Yañes-Arancibia, 2014). The fact that $60 \%$ of municipalities present low levels in terms of this last indicator reflects low economic productivity, since it represents the relative weight of the Gross Domestic Product (GDP). This implies that to adapt to climate change, municipalities should implement solutions that improve social and economic conditions and involve other complementary measures such as ecosystem-based adaptation (EbA). This is related to the use of biodiversity and ecosystem services for adaptation (Reguero et al., 2016), which has already been applied to climate adaptation plans in Europe and shows great potential in the face of the challenges of climate change (Geneletti and Zardo, 2016). Also useful is communitybased adaptation $(\mathrm{CbA})$ where communities are empowered with processes to reduce vulnerability and increase adaptive capacity (Galindo et al., 2017); and those useful measures according to present conditions.

The possible losses in tourist areas are important impacts, since this activity represents the vocation of many coastal municipalities such as Buenaventura (Arboleda, 2017). These impacts become relevant when considering 
Los altos niveles de pobreza (NBI de 78\%) presentes en los municipios costeros del país en combinación con bajos niveles de importancia económica municipal, podrían incrementar la vulnerabilidad al cambio climático (Yáñez-Arancibia, 2014; Musetta et al., 2017).El hecho de que $60 \%$ de los municipios tengan niveles bajos en este último indicador refleja una baja productividad económica, pues el mismo representa el peso relativo del Producto Interno Bruto (PIB). Esto implica que, la manera de encaminarse hacia la adaptación al cambio climático en los municipios, es practicando soluciones que integren el mejoramiento de las condiciones sociales y económicas, acompañadas de otras medidas complementarias como la adaptación basada en ecosistemas (AbE), relacionada con el uso de la biodiversidad y los servicios ecosistémicos para la adaptación (Reguero et al., 2016), que ya ha sido aplicada a planes de adaptación al clima en Europa y tienen gran potencial frente a los desafíos del cambio climático (Geneletti y Zardo, 2016); y la adaptación basada en comunidades $(\mathrm{AbC})$ donde estas son empoderadas de los procesos para disminuir la vulnerabilidad e incrementar la capacidad adaptativa (Galindo et al., 2017); y todas aquellas medidas útiles de acuerdo a las condiciones presentes.

Las posibles pérdidas en las áreas turísticas son impactos importantes, pues esta actividad representa la vocación de muchos municipios costeros como Buenaventura (Arboleda, 2017). Estos impactos cobran relevancia al considerar que las economías locales tienen alta dependencia a este sector y además dicha actividad es sensible a eventos climáticos extremos. En tal sentido, existen municipios en la región Pacífica que han considerado el turismo en sus planes de desarrollo y prevén incrementar su intensidad; sin embargo, la mayor pérdida de área turística debido a la erosión costera se espera en esta zona (cercana a 16\%); de ahí la importancia de apuntar al fortalecimiento y creación de alternativas de adaptación específicas para el sector.

En la infraestructura, por su parte, resalta una posible afectación de 5,9\% del total de las áreas de zonas portuarias marítimas del país debido a inundaciones por ANM, principalmente en los puertos de Tumaco y Buenaventura en la región Pacífica; lo cual está relacionado con el estudio de Reyer et al. (2015) realizado para América Latina, donde se establece que puertos importantes como los de Cartagena y Barranquilla podrían ser impactados negativamente por esta amenaza, con consecuencias sobre los precios de bienes comercializados en el exterior. Sin that local economies are highly dependent on this sector and the activity is also sensitive to extreme weather events. In this sense, there are municipalities in the Pacific region that have considered tourism in their development plans and aim to increase its intensity. However, the greatest loss of tourist area due to coastal erosion is expected in this sphere (about $16 \%$ ), hence, the importance of strengthening and creating adaptation alternatives specific to the sector.

In infrastructure, a possible affectation of $5.9 \%$ of the total areas of the country's maritime port zones is highlighted due to flooding by SLR, especially in the ports of Tumaco and Buenaventura in the Pacific region. This is related to the study by Reyer et al. (2015) for Latin America, which establishes that important ports such as those of Cartagena and Barranquilla could be negatively impacted by this threat, with consequences on the prices of goods traded abroad. However, to the extent that annual investments are maintained in these areas, they may be highly adaptive.

In order to improve the results obtained in this study, in the future, the databases used in the methodology could be enriched, based on the possible availability of official sources of information, which offer data at more detailed scales and diminish uncertainty in the estimates. It may be beneficial to analyze the possibility of increasing the number of indicators, in order to include other socioeconomic elements such as health, education, basic sanitation, incomegenerating capacities and social mobility, which account for societies' sensitivity and adaptive capacity and to identify the impacts on other economic activities present in the coastal marine zone, such as fishing and aquaculture. In turn, existing indicators could be strengthened by including specific information such as the impact on the variety of crops and hotel infrastructure.

\section{CONCLUSIONS}

This study offers an approach to the socioeconomic impacts caused by climate change in the country's coastal municipalities due to threats of SLR and coastal erosion. It offers input for territorial planning and the elaboration of climate change management plans and serves as a contribution to the coastal marine component of the Third National Communication on Climate Change (TCNCC). It made it possible to identify the threats, sensitivity and adaptive capacity of several elements relevant to the study area, allowing an approximation to the municipalities' weaknesses and possibilities in terms of adaptation to climate change. 
embargo, en la medida en que se mantengan las inversiones anuales en estas zonas podrán tener una alta capacidad de adaptación.

Con el fin de mejorar los resultados obtenidos en este estudio, a futuro podrían alimentase las bases de datos utilizadas en la metodología, partiendo de la posible disposición de fuentes de información oficiales, que ofrezcan datos a escalas más detalladas y permitan disminuir la incertidumbre en las estimaciones. Es conveniente analizar la posibilidad de incrementar el número de indicadores, con el fin de incluir otros elementos socioeconómicos como la salud, la educación, el saneamiento básico, las capacidades para la generación de ingresos y la movilidad social, que den cuenta sobre la sensibilidad y la capacidad adaptativa de las sociedades. E identificar los impactos en otras actividades económicas presentes en la zona marino- costera, como la pesca y la acuicultura; a su vez, los indicadores existentes podrían fortalecerse, al incluir información específica como la afectación de la variedad de cultivos e infraestructura hotelera.

\section{CONCLUSIONES}

Este estudio ofrece un acercamiento a los impactos socioeconómicos causados por el cambio climático en los municipios costeros del país debido a las amenazas de ANM y erosión costera, es un insumo para el direccionamiento en la planificación territorial y la elaboración de los planes de gestión del cambio climático y fue un aporte para el componente marino costero de la Tercera Comunicación Nacional de Cambio Climático (TCNCC). Se logró la identificación de las amenazas, sensibilidad y capacidad adaptativa de varios elementos relevantes para el área de estudio, lo cual permitió hacer una aproximación a las debilidades y posibilidades de los municipios en materia de adaptación al cambio climático.

Los resultados obtenidos presentan similitudes con otros estudios sobre impactos del cambio climático realizados en América Latina y específicamente en países costeros como Venezuela, Uruguay y Perú, con posibles afectaciones en los hábitats humanos, principalmente en las poblaciones y las actividades productivas como el turismo.

La pobreza medida a través del NBI, en combinación con las bajas proporciones en la producción económica (calculada a través de la importancia económica municipal), indican una alta sensibilidad de los municipios costeros; esto refleja la necesidad de plantear acciones que abarquen la gestión social y productiva acompañada de alternativas
The results obtained show similarities with other studies on the impacts of climate change on Latin America and specifically on coastal countries such as Venezuela, Uruguay and Peru, with possible effects on human habitats, mainly on populations and productive activities such as tourism.

Poverty measured through UBN, combined with low proportions of economic production (calculated through municipal economic importance), indicate high sensitivity of coastal municipalities, reflecting the need for actions that encompass social and productive management accompanied by alternatives such as ecosystem-based adaptation (EBA) and community-based adaptation (CBA). The planning of climate change management in productive activities is important, mainly those that are vocational and of high economic dependence such as tourism, given the high probability of affectation, especially in the Colombian Pacific region.

The maritime port infrastructure could be affected by SLR, causing negative impacts on much of the international trade activities. This threat must therefore be considered in port plans and as long as annual investments are maintained in these areas, they may be highly adaptive.

Climate threats affect coastal municipalities differently, which is why vulnerability and risk studies should be undertaken for each of them in order to generate adaptation measures in accordance with their characteristics and reduce the social and economic effects. This study is a contribution to the continuity of the climate change management process in Colombia, and has been used as input for the preparation of some coastal climate change plans.

Such studies need to be updated over time in order to identify the changes in the impacts and dynamics of the threats of climate change, and to foresee possible accelerations in the effects and thus apply rapid responses that prevent an increase in the possible damage.

\section{ACKNOWELDGEMENTS}

The authors would like to thank the Instituto de Investigaciones Marinas y Costeras - Invemar and the Instituto de Hidrología, Meteorología y Estudios Ambientales -IDEAM for the elaboration of the Coastal and Insular Marine Vulnerability Analysis of the Third National Communication on Climate Change for Colombia. Contribution $\mathrm{N}^{\circ} 1124$, Invemar. 
como la adaptación basada en ecosistemas (AbE) y la adaptación basada en comunidades (AbC). Es importante la planificación de la gestión ante cambio climático en las actividades productivas, principalmente las de vocación y de alta dependencia económica como el turismo, dada una alta probabilidad de afectación especialmente en la región Pacífica colombiana.

La infraestructura portuaria marítima podría ser afectada por el ANM, causando impactos negativos en gran parte de las actividades de comercio internacional. Por tal razón esta amenaza debe ser considerada en los planes portuarios y en la medida en que se mantengan las inversiones anuales en estas zonas, podrán tener una alta capacidad de adaptación.

Las amenazas climáticas afectan a los municipios costeros de forma distinta, por lo tanto, es necesario que cada uno cuente con estudios de vulnerabilidad y riesgo; con la finalidad de generar medidas de adaptación acordes a las características de los territorios y reducir los efectos a nivel social y económico. Este estudio es un aporte en la continuidad del proceso de gestión ante cambio climático en Colombia; y se ha constituido en el insumo para la elaboración de algunos planes de cambio climático a nivel costero.

Se requiere mantener la actualización de este tipo de estudios en el tiempo, para identificar los cambios en los impactos y las dinámicas de las amenazas del cambio climático, con el fin de prever posibles aceleraciones en los efectos y aplicar respuestas rápidas que prevengan el incremento en la magnitud de los posibles daños.

\section{AGRADECIMIENTOS}

Al Instituto de Investigaciones Marinas y Costeras - Invemar y al Instituto de Hidrología, Meteorología y Estudios Ambientales -IDEAM, en el marco de la elaboración del Análisis de Vulnerabilidad Marino Costero e Insular de la Tercera Comunicación Nacional de Cambio Climático para Colombia. Contribución $N^{\circ} 1124$, Invemar. 


\section{BIBLIOGRAFÍA / LITERATURE CITED}

Allison, E., A. Perry, M. Badjeck, W. Adger, K. Brown, D. Conway, A. Halls, G. Pilling, J. Reynolds, N. Andrew and N. Dulvy. 2009. Vulnerability of national economies to the impacts of climate change on fisheries. Fish and Fish., 10 (2): 173 - 196. https://doi.org/10.1111/j.1467-2979.2008.00310.x

Arboleda, N. 2017. Lineamientos estratégicos para la gestión del turismo en el distrito de Buenaventura (Colombia). Tur. Soc., 23: 237-266.

Armanfar, M., H. Goharnejad, M. Zakeri Niri and W. Perrie. 2019. Assessment of coastal vulnerability in Chabahar Bay due to climate change scenarios. Oceanologia. https://doi.org/10.1016/j.oceano.2019.03.001.

Banco Interamericano de Desarrollo - BID. 2010. Vulnerabilidad y adaptación al cambio climático Diagnóstico inicial, avances, vacíos y potenciales líneas de acción en Mesoamérica. Washington, D.C. 110 p.

Benjumea, J., D. Fernández, M. Márquez, J. Núñez y J. Vilches. 2006. Matemáticas avanzadas y estadística para ciencias e ingenierías. Universidad de Sevilla, Sevilla. $271 \mathrm{p}$.

Binita, K., M. Shepherd and C. Johnson. 2015. Climate change vulnerability assessment in Georgia. App. Geogr., 62: 62 - 74. https://doi.org/10.1016/j. apgeog.2015.04.007

Camare, H. and D. Lane. 2015. Adaptation analysis for environmental change in coastal communities, Socio-Econ. Plan. Sci., 51:34-45.

Da Cruz, G. 2009. Cambio climático y turismo posibles consecuencias en los destinos turísticos de Bahía - Brasil. Est. Persp. Tur., 18 (4): 476 - 489.

Day, J., A. Yáñez-Arancibia y J. Rybczyk. 2011. Cambio climático: efectos, causas, consecuencias: cambios físicos, hidromorfológicos, ecofisiológicos y biogeográficos. Módulo Referencia Sistemas Terrestres y Ciencias Ambientales. Trat. Estuario Cienc. Cost., 8: 303-315. https://doi.org/10.1016/ B978-0-12-374711-2.00815-9.

Departamento Administrativo Nacional de Estadística - DANE. 2012. Indicador de importancia económica municipal, Cuentas nacionales departamentales, https://www.dane.gov.co/index.php/estadisticas-por-tema/cuentas-nacionales/cuentas-nacionales-departamentales/indicador-de-importanciaeconomica-municipal. 15/10/2016.

Diez, J. 2000. A review of some concepts involved in the sea-level rise problem. J. Coast. Res., 16(4):1179-1184.

Ding, Q., C. Xinjun, R. Hilborn and Y. Chen. 2017. Vulnerability to impacts of climate change on marine fisheries and food security. Mar. Pol., 83: 55 - 61. Doi: 10.1016/j.marpol.2017.05.011.

Galindo, A., J. Pérez y R. Rojano. 2017. Medidas de adaptación al cambio climático en una comunidad indígena del norte de Colombia. Rev. U.D.C.A. Act. Div. Cient., 20(1): 187 - 197.

Gallopin, G. 2006. Linkages between vulnerability, resilience, and adaptive capacity. Global Environ. Change, 16 (3): 293-303. https://doi.org/10.1016/j. gloenvcha.2006.02.004

Geneletti, D. and L. Zardo. 2016. Ecosystem-based adaptation in cities: An analysis of European urban climate adaptation plans. Land Use Pol., 50: $38-47$. https://doi.org/10.1016/j.landusepol.2015.09.003.

Giménez, A. y B. Lanfranco. 2012. Adaptación al cambio climático y la variabilidad: algunas opciones de respuesta para la producción agrícola en Uruguay. Rev. Mex. Cienc. Agr., 3(3):611-620.

IDEAM - PNUD. 2001. Primera comunicación nacional ante la Convención Marco de las Naciones Unidas sobre el Cambio Climático. Bogotá. 267 p.

IDEAM - PNUD. 2010. Segunda comunicación nacional ante la Convención Marco de las Naciones Unidas sobre Cambio Climático. Bogotá. 440 p.

IDEAM, PNUD, MADS, DNP y CANCILLERÍA. 2017. Tercera comunicación nacional de Colombia a la Convención Marco de las Naciones Unidas sobre Cambio Climático (CMNUCC). IDEAM, PNUD, MADS, DNP, CANCILLERÍA, FMAM. Bogotá D.C.

INVEMAR - IDEAM. 2017. Elaboración del análisis de vulnerabilidad marino costero e insular ante el cambio climático para el país. Inf. Técn. Final (ITF) - 001. Contrato con el Programa de las Naciones Unidas para el Desarrollo - PNUD, Nº 0000040357 . Santa Marta. 256 p.

Intergovernmental Panel on Climate Change - IPCC. 1995. IPCC Second Assessment Climate Change 1995. Contribution of Working Groups I, II and III to the Second Assessment Report of the Intergovernmental Panel on Climate Change. Cambridge University Press, New York. 73 p.

Intergovernmental Panel on Climate Change - IPCC. 2014. Climate Change 2014: Impacts, Adaptation, and Vulnerability. Part A: Global and Sectoral Aspects. Contribution of Working Group II to the Fifth Assessment Report of the Intergovernmental Panel on Climate Change. Cambridge University Press, Cambridge, United Kingdom and New York. 1132 p.

Klein, R., R. Nicholls, S. Ragoonaden, M. Capobianco, J. Aston and E. Buckley. 2001. Technological options for adaptation to climate change in coast. J. Coast. Res., 17(3): 531-543.

Kokot, R., J. Codignotto y M.Elissondo. 2004. Vulnerabilidad al ascenso del nivel del mar en la costa de la provincia de Río Negro. Rev. Asoc. Geol. Arg., 59(3): 477-487.

Kuok Ho, D. 2019. Climate change in Malaysia: Trends, contributors, impacts, mitigation and adaptations. Sci. Total Environ., 650(2):1858-1871. https:// doi.org/10.1016/j.scitotenv.2018.09.316.

Lampis, X. 2013. Vulnerabilidad y adaptación al cambio climático: Debates acerca del concepto de vulnerabilidad y su medición. Cuad. Geogr., Rev. Col. Geogr., 22(2): 17-33. 
Ministerio del Medio Ambiente - MINAMBIENTE. 2001. Pronunciamiento sobre los estudios y propuestas de zonificación en áreas de manglares jurisdicción de CARSUCRE, CORALINA, CORPAMAG, CRA, CVS y CVC y, se adoptan otras determinaciones. Bogotá. 45 p.

Mussetta, P., M. Barrientos, E. Acevedo, S. Turbay y O. Ocampo. 2017. Vulnerabilidad al cambio climático: Dificultades en el uso de indicadores en dos cuencas de Colombia y Argentina. Rev. Metodol. Cienc. Soc., (36): 119-147. Doi/ empiria.36.2017.17862.

Nagy, G., O. Gutiérrez, E. Brugnoli, J. Verocai, M. Gómez-Erache, Al Villamizar, I. Olivares, U. Azeiteiro, W. Leal and N. Amaro. 2019. Climate vulnerability, impacts and adaptation in Central and South America coastal areas. Reg. Stud. Mar. Sci., https://doi.org/10.1016/j.rsma.2019.100683.

Olivo, M., E. Lettherny, C. Platt y M. Sosa. 2001. Pérdidas de tierra en la costa venezolana debido al incremento del nivel del mar. Interciencia, 26(10): 463-468.

Olivo-Garrido, M., V. Sáez-Sáez, A. Martín-Zazo y A. Soto-Olivo. 2012. Vulnerabilidad al incremento del nivel del mar: estrategias de adaptación en el área Cabo Codera-Laguna de Tacarigua, estado Miranda, Venezuela. Terra Nueva Etapa, 28(43): 45-70.

Panel Intergubernamental de Cambio Climático - IPCC. 1990. Resuman General Primer Informe de Evaluación del IPCC. Contribución de los Grupos de Trabajo I, II, y III al Primer Informe de Evaluación del Grupo Intergubernamental de Expertos sobre el Cambio Climático, Ginebra. 14 p.

Panel Intergubernamental de Cambio Climático - IPCC. 2001. Cambio climático 2001: Informe de síntesis, contribución de los Grupos de Trabajo I, II, y III al Tercer Informe de Evaluación del Grupo Intergubernamental de Expertos sobre el Cambio Climático, IPCC, Ginebra. 172 p.

Panel Intergubernamental de Cambio Climático - IPCC. 2007. Contribución de los Grupos de Trabajo I, II y III al Cuarto Informe de Evaluación del Panel Intergubernamental sobre el Cambio Climático, IPCC, Ginebra. 104 p.

Petzold, J. and R. Beate. 2015. Climate change adaptation under a social capital approach e ananalytical framework for small islands. Ocean Coast. Manag., 112:36-43.

Ramos-Reyes, R., J. Zavala-Cruz, L. Gama-Campillo, D. Pech-Pool y M. Ortiz-Pérez. 2016. Indicadores geomorfológicos para evaluar la vulnerabilidad por inundación ante el ascenso del nivel del mar debido al cambio climático en la costa de Tabasco y Campeche, México. Bol. Soc. Geol. Mex., 68(3): 581-598. Doi: 10.18268/BSGM2016v68n3a12.

Reguero, B., M. Beck, I. Losada y S. Narayan. 2016. Uniendo ingeniería y ecología: la protección costera basada en ecosistemas. Ribagua - Rev. Iberoam. Agua. Doi: 10.1016/j.riba.2016.06.002.

Reyer, C., S. Adams, T. Albrecht, F. Baarsch, A. Boit, N. Canales, M. Cartsburg, D. Coumou, A. Eden, F. Fernandes, F. Langerwisch, R. Marcus, M. Mengel, D. Mira-Salama, M. Perette, P. Pereznieto, A. Rammig, J. Reinhardt, A. Robinson, M. Rocha, B. Sakschewski, M. Schaeffer, C. Schleussner, O. Serdeczny and K. Thonicke. 2015. Climate change impacts in Latin America and the Caribbean and their implications for development. Internat. Bank Reconstr. Devel./The World Bank. DOI 10.1007/s10113-015-0854-6.

Slangen, A., J. Church, X. Zhang and D. Monselesan. 2014. Detection and attribution of global mean thermosteric sea level change. Geophys. Res. Lett., 41: 5951-5959. https://doi.org/10.1002/2014GL061356.

Tejeda, R. 2018. Sectores costeros más vulnerables entre Lurín y Pucusana ante un posible aumento del nivel del mar como consecuencia del cambio climático: adaptación y aplicación del índice de vulnerabilidad costera de Gornitz (1991). Esp. Des., 31: 59-86. https://doi.org/10.18800/ espacioydesarrollo.201801.003.

Tragaki, A., C. Gallousi and E. Karymbalis. 2018. Coastal hazard vulnerability assessment based on geomorphic, oceanographic and demographic parameters: The case of the Peloponnese (southern Greece). Land, 7 (2): 56. Doi:10.3390/land7020056.

Vargas A. 1995. Estadística descriptiva e inferencial. Universidad de Castilla-La Mancha. Ciudad Real, España. 577 p.

Vides, M. y P. Sierra-Correa. 2014. Análisis de normativa ambiental y mapeo institucional: hacia una política climática integrada para reducir el riesgo asociado al aumento en el nivel del mar en el Caribe colombiano. Bol. Invest. Mar. Cost.,43(2): 307-328.

Yáñez-Arancibia, A., J. Day, R. Twilley y R. Day. 2014. Manglares frente al cambio climático, ¿tropicalización global del Golfo de México? Mad. Bosq., 20 (3): 39-75.

Wong, P., I. Losada, J. Gattuso, J. Hinkel, A. Khattabi, K. McInnes, Y. Saito y A. Sallenger. 2014. Cambio climático 2014: impactos, adaptación y vulnerabilidad. Parte A: Aspectos globales y sectoriales. Sistemas costeros y áreas bajas. Contrib. Grupo Trab. II Quinto Inf. Eval. Panel Intergubern. Cambio Clim. 361-409. 